\title{
Sex cord-stromal tumors of the ovary and testis: their similarities and differences with consideration of selected problems
}

\author{
Robert H Young \\ James Homer Wright Pathology Laboratories of the Massachusetts General Hospital, Department of \\ Pathology, Harvard Medical School, Boston, MA, USA
}

\begin{abstract}
Gonadal sex cord-stromal tumors contain some of the most morphologically interesting neoplasms of the gonads and these lead to many important issues in differential diagnosis. The pathology of these tumors is reviewed with emphasis on new information, similarities and differences in the two gonads, and diagnostic problems. Sertoli cell tumors occur in both gonads being more common in the testis where they usually exhibit a lobular pattern of hollow or solid tubules. In the ovary, tubular differentiation is usually the predominant feature but the lobulation typically seen in the testis is generally not as striking. One variant of Sertoli cell tumor, the large cell calcifying form, appears to be restricted to the male gonad and in contrast to other sex cord tumors is much more frequently bilateral and is associated in many cases with unusual clinical manifestations. In both sexes, patients with Peutz-Jeghers syndrome often have distinctive gonadal pathology. In females, it is in the form of the sex cord with annular tubules whereas in males, the lesion has features that are often intermediate between those of a sex cord tumor with annular tubules and a large cell calcifying Sertoli cell tumor. Sertoli-Leydig cell tumors are more morphologically diverse than pure Sertoli cell tumors and for practical purposes are an issue only in ovarian pathology being exceptionally rare in the testis. The classification proposed by Meyer into well, intermediate, and poor differentiation, remains important prognostically. More recently, heterologous and retiform differentiation has been described. Heterologous tumors most often contain mucinous epithelium, sometimes with small foci of carcinoid or less commonly, and generally in poorly differentiated neoplasms, rhabdomyosarcoma or fetal-type cartilage. Such tumors should be distinguished from pure sarcomas and teratomas. The retiform neoplasms, which tend to occur in young females, may mimic serous borderline tumors or even serous carcinomas. Granulosa cell tumors are much more common in females and in both gonads are divided into adult and juvenile forms. In females, granulosa cell tumors and other sex cord tumors may have markedly bizarre nuclei potentially leading to overdiagnosis as more malignant neoplasms. The juvenile granulosa cell tumor of the testis tends to occur in the first 6 months of life and should be carefully distinguished from the yolk sac tumor of the testis, which usually occurs in a slightly older age group. Occasional sex cord-stromal tumors cannot be readily categorized into the Sertoli or granulosa families and are diagnosed as sex cord-stromal tumors unclassified. In females, this is a relatively common placement for a neoplasm in a pregnant patient. Unclassified tumors are overall more common in males and may entrap residual normal germ cells potentially leading to the erroneous placement of the tumor in the category of a mixed germ cell sex cord-stromal tumor. From the practical viewpoint, the most helpful immunohistochemical findings are the negative staining of sex cord tumors for epithelial membrane antigen, and positive staining for inhibin and calretinin, findings that are converse to those seen in endometrioid carcinomas of the ovary, which commonly have formations that simulate sex cord tumors.
\end{abstract}

Modern Pathology (2005) 18, S81-S98. doi:10.1038/modpathol.3800311

Keywords: ovary; testis; sex cord tumors; Sertoli cell tumor; granulosa cell tumor

Correspondence: Dr RH Young, MD, Department of Pathology, Massachusetts General Hospital, Warren Building, Fruit Street, Boston, MA 02114, USA.

E-mail: rhyoung@partners.org

Received and accepted 30 August 2004
The family of sex cord-stromal tumors contains some of the most morphologically interesting of all gonadal neoplasms and a strong interest in these links three of the giants of pathology: Dr Robert Meyer, ${ }^{1}$ Dr Gunnar Teilum, ${ }^{2}$ and Dr Robert Scully. ${ }^{3}$ 
The contributions of these three individuals is largely what has brought about the current state of knowledge in this area of gonadal pathology.

Endocrine function is relatively common in association with these neoplasms and can account for occasional striking clinical manifestations. The combined clinical and pathologic features result in individual cases being among the most intriguing encountered in the practice of medicine. Although all neoplasms in this category, except ovarian fibromas, are uncommon, their microscopic features may be mimicked by many other neoplasms, particularly in the ovary. Accordingly, sound knowledge of their morphologic variants and mimics is crucial in gonadal tumor interpretation. As the title of this contribution suggests, I will follow the lead of Dr Teilum whose important contributions to our knowledge of sex cord tumors are noted in the historical introduction to this long course, and consider each category of neoplasm in the two gonads, as he $\mathrm{did},{ }^{2}$ from the comparative viewpoint where indicated. Excluded from consideration are pure stromal neoplasms because in the testis they are exceptionally rare and in the ovary, with occasional exceptions, are generally straightforward microscopic interpretations. I shall begin with the neoplasms that in both recent gonadal tumor fascicles ${ }^{4,5}$ are considered Sertoli-stromal cell tumors. These tumors are comprised by pure Sertoli cell tumors and those with an additional stromal component, the Sertoli-Leydig cell tumors (SLCTs). As almost all references are easily available in the texts just mentioned only selected papers are cited here.

\section{Sertoli cell tumors}

A classification of these tumors is given in Table 1 with an indication as to whether a specific subtype occurs in one or both gonads. Although there are striking similarities between Sertoli cell tumors in the two gonads, there are also significant differences in as much as certain subtypes of Sertoli cell tumor seen in the testis (large cell calcifying and sclerosing) are almost nonexistent in the ovary. The lipidrich Sertoli cell tumor is listed in the table but not considered in the testis section as valid testicular examples are so few. The sclerosing Sertoli cell tumor is not given a separate heading here.

Sertoli cell tumors are rare neoplasms in either gonad, it not being possible to establish reliably whether they are more common in one or the other. We have, however, seen approximately twice as many testicular, as ovarian, examples. As the

Table 1 Classification of gonadal Sertoli cell tumors

Sertoli cell tumor, not otherwise specified (both gonads)

Lipid-rich (almost always ovary)

Large cell calcifying (testis only)

Sclerosing (almost always testis) differential diagnosis is broader in the ovary, given the greater number of mimics seen in that gonad, it has been more difficult to establish a consistent morphologic profile in the ovary than in the testis. However, immunohistochemical markers now exist that can be strongly supportive of the diagnosis of Sertoli cell tumor, or alternatively argue strongly against it, as considered at the end of this handout. This adjunct is needed much more often in the ovary than in the testis. As the tumors are more common in the testis and the morphologic profile is somewhat better established in that gonad, testicular neoplasms are considered first.

\section{Testicular Sertoli Cell Tumors}

Sertoli cell tumor, not otherwise specified

These tumors may occur throughout life but are rare in the first decade and have a peak frequency in the range of 35 to 50 years of age (mean age 45 years), ${ }^{6}$ placing them usually within the germ cell tumor age group, something of note given the potential for malignant Sertoli cell tumors to be misdiagnosed as seminoma, ${ }^{7}$ as discussed below. They are almost invariably unilateral and have no distinctive clinical features. Hormonal manifestations are rare in our experience; the literature suggests that gynecomastia is seen in about $25 \%$ of the cases but many of these tumors likely belong to other categories within the sex cord-stromal family. The patient will sometimes recount having been aware of a mass for many years. Metastasis accounts for the presentation in only about $7 \%$ of the cases. ${ }^{6}$

The well-differentiated tumors are typically in the range of 3 to $4 \mathrm{~cm}$ in greatest dimension with only about $25 \%$ over $5 \mathrm{~cm}$. They are typically well circumscribed, and usually have a solid sectioned surface, but cysts are present in about one-third of them. The tumor tissue is typically tan, gray, or white, but may be yellow and in some cases hemorrhage may be present. Necrosis is rare in low-grade tumors. When the tumor is white and lobulated, the gross appearance of seminoma is simulated (Figure 1).

Microscopic examination shows a spectrum from well-differentiated neoplasms with exquisite tubular differentiation to poorly differentiated neoplasms with limited, or in some instances, absent tubular differentiation (Figures 2-11). ${ }^{6-9}$ Low-power examination of the former often shows a striking nodular pattern, with the nodules separated by acellular, often vascular fibrous stroma, the vessels sometimes being dilated (Figure 2). This results in a relatively distinctive profile on low-power examination and on the basis of personal experience probably accounts for the morphology of approximately $50 \%$ of the low-grade neoplasms. The cellular elements within the nodules or in diffuse areas, which may sometimes be conspicuous and rarely dominate, typically have overt tubular differentiation at least focally (Figure 3 ). This may be in 


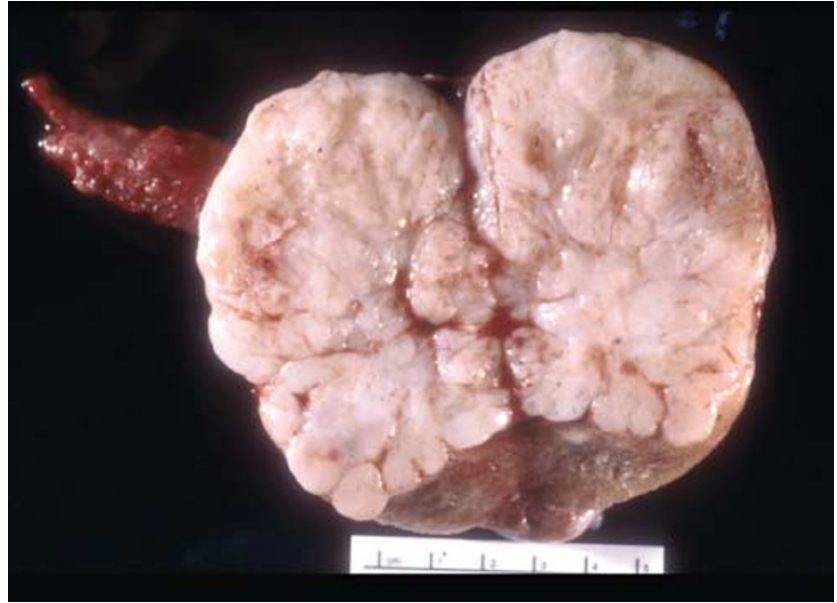

Figure 1 Sertoli cell tumor of testis. The white, lobulated tumor was indistinguishable grossly from seminoma.

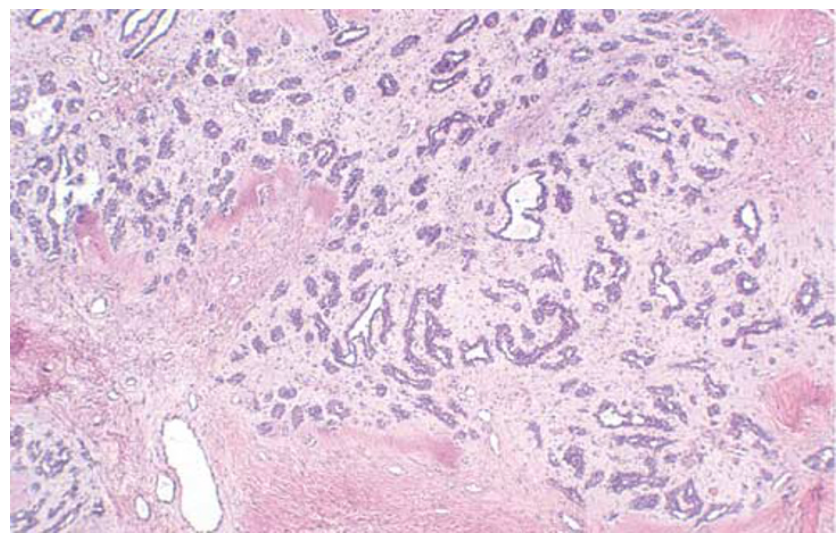

Figure 2 Sertoli cell tumor of testis. Well-differentiated tumors often have a prominent fibrous stroma and a lobulated arrangement of aggregates of tubules.

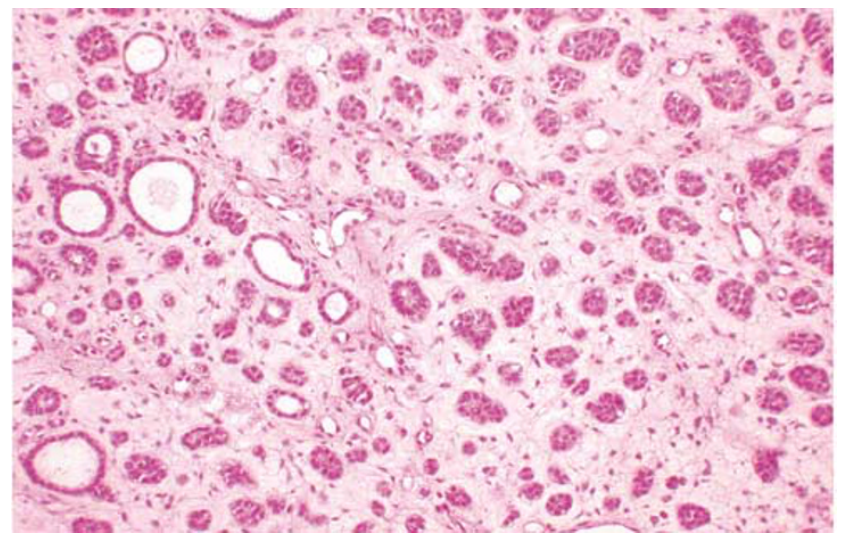

Figure 3 Sertoli cell tumor of testis. Solid and hollow tubules are evident.

the form of hollow tubules, sometimes dilated, or solid tubules. The tubules may be lined by lipid-rich cells (Figure 5) but testicular tumors entirely of this type are rare. Thick ribbons and occasionally

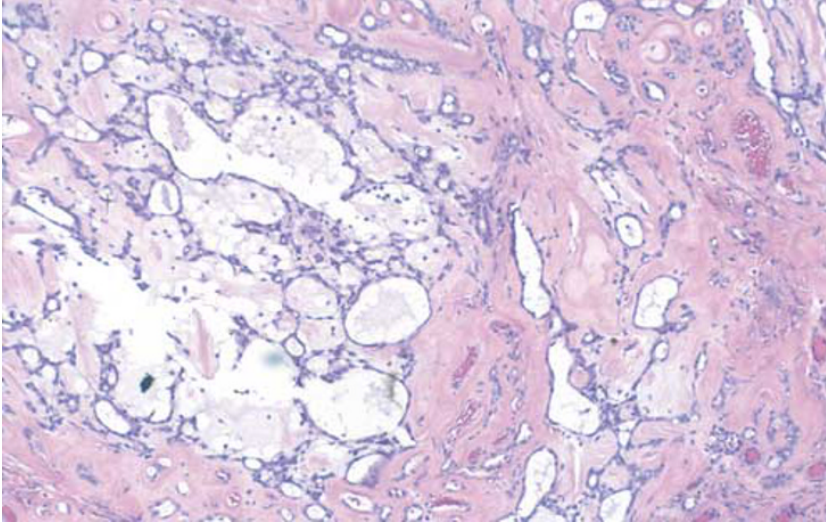

Figure 4 Sertoli cell tumor of testis. Elongated spaces and microcysts produce a picture potentially confusable with a yolk sac tumor.

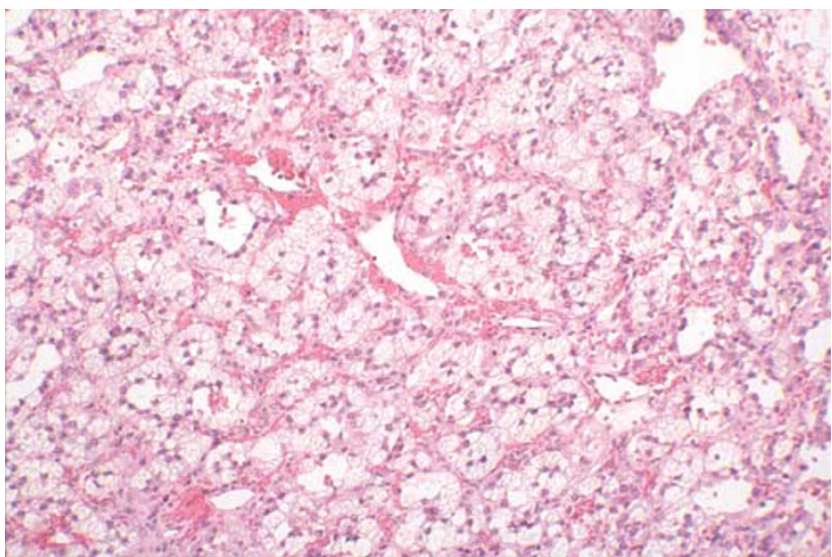

Figure 5 Sertoli cell tumor of testis. The tumor cells have abundant pale lipid-rich cytoplasm.

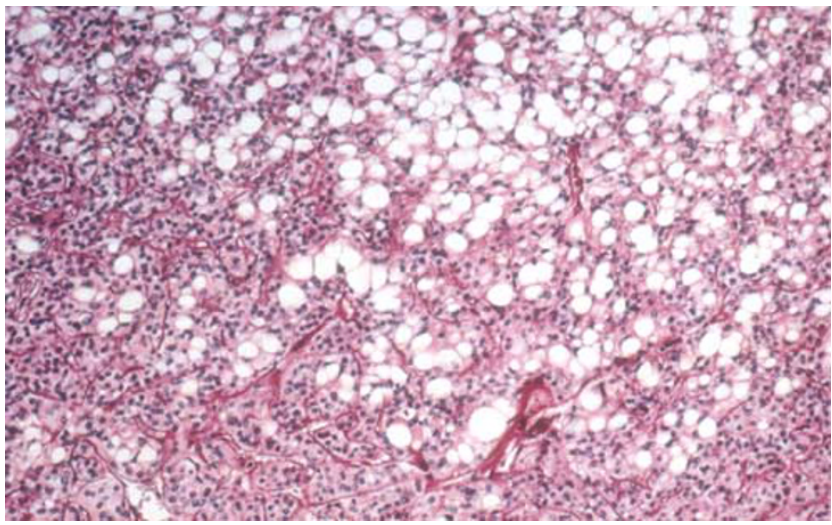

Figure 6 Sertoli cell tumor of testis. Large lipid-filled vacuoles are conspicuous on low power.

delicate thin cords may also be present. Rarely, the tubules produce a striking ramifying pattern and exceptionally they have a retiform morphology. Numerous hyaline bodies were present in one case, 


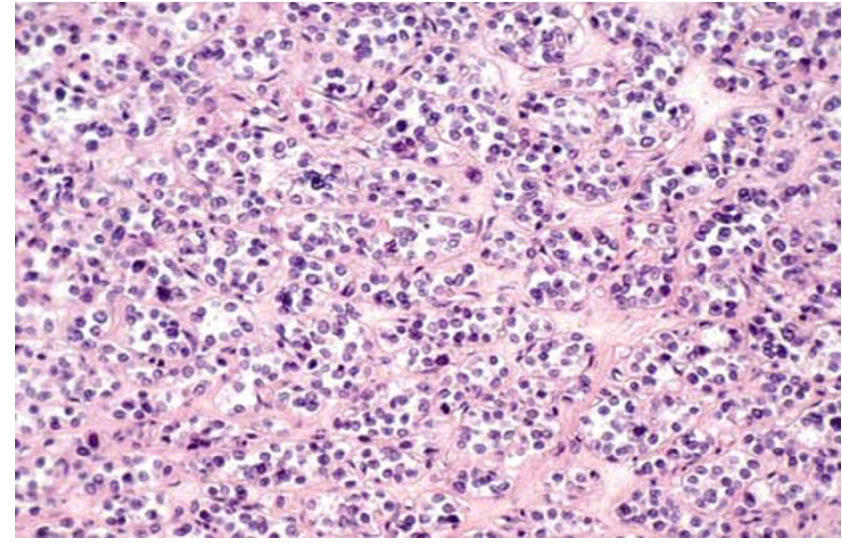

Figure 7 Sertoli cell tumor of testis. This tumor has a largely diffuse pattern and was clinically malignant.

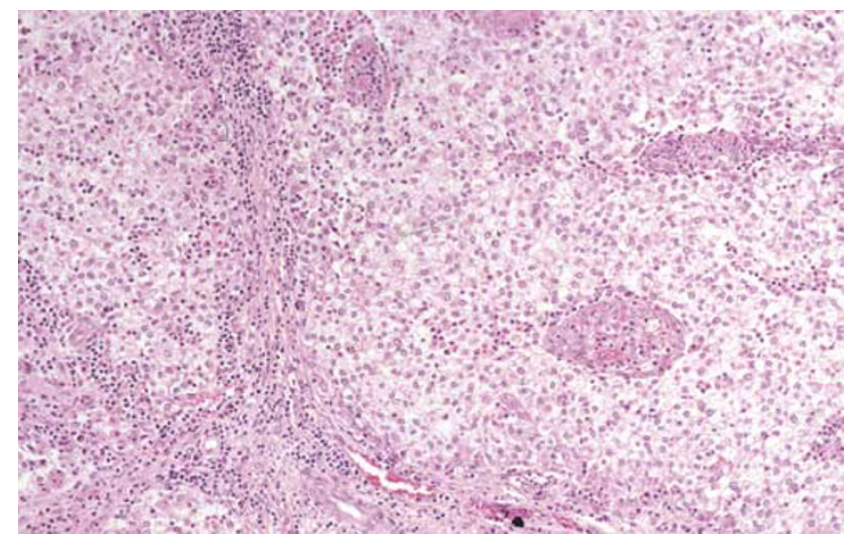

Figure 8 Sertoli cell tumor of testis. This tumor has fibrous septa with lymphocytes sprinkled along them. This appearance may be confused with seminoma.

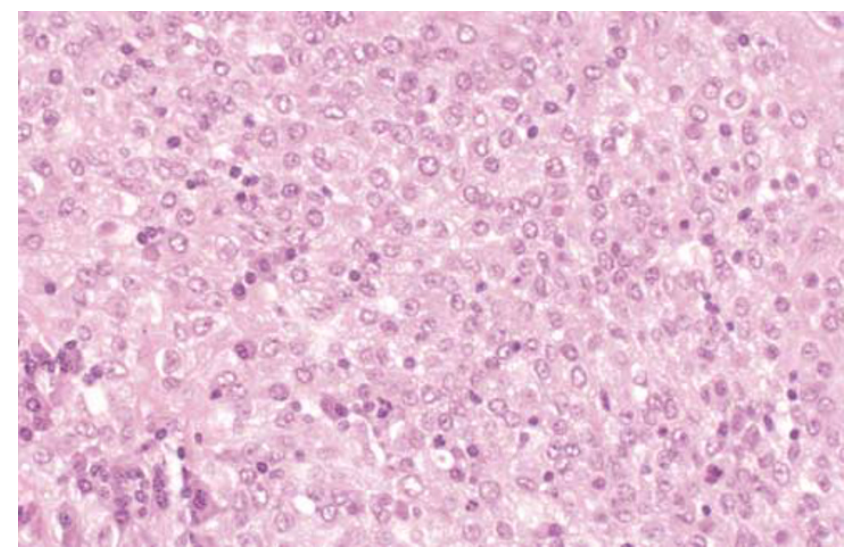

Figure 9 Sertoli cell tumor of testis. High-power view of a tumor that had a seminoma-like picture on low power. The nuclei do not have the squared-off edges typical of seminoma cells, and nucleoli are not prominent.

indicating the nonspecific nature of this finding in gonadal tumor pathology. Another tumor contained osteoclast-like giant cells (Ulbright TM, personal communication).

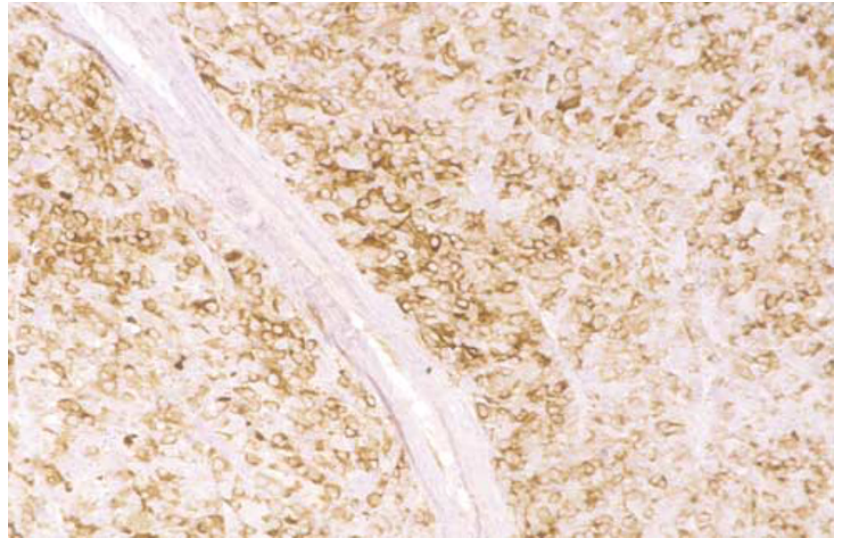

Figure 10 Sertoli cell tumor of testis. There is strong immunoreactivity for inhibin.

The usually fibrous stroma may be extensively hyalinized and rupture of blood vessels may result in recent or old hemorrhage. In some cases, most of the tumor is composed of sclerotic stroma giving rise to the descriptive category of 'sclerosing Sertoli cell tumor' (Figure 11). ${ }^{10}$

The tumor cells are typically polygonal with moderate to abundant amounts of pale cytoplasm; vacuoles, due to intracytoplasmic lipid, are conspicuous in almost half of them (Figure 6). A minority $(<20 \%)$ of tumors have cells with abundant eosinophilic cytoplasm. Tumors with a welldifferentiated tubular morphology generally have absent or infrequent mitotic figures but rarely the mitotic rate is brisk, particularly in tumors with diffuse growth. In one series of 60 unselected Sertoli cell tumors, NOS only $16 \%$ had brisk mitotic rate. ${ }^{6}$ Nuclear atypicality is mild at most in about $90 \%$ of the tumors. ${ }^{6}$ Nuclear grooves may be seen but are generally inconspicuous.

In contrast to the above are rare less welldifferentiated Sertoli cell tumors with a more or less diffuse pattern and less conspicuous stroma than seen in well-differentiated neoplasms (Figure 7). However, a minor stromal component is still often present and may produce a delicate nested pattern that, particularly when associated with cells with clear cytoplasm and an inflammatory cell infiltrate, may simulate the alveolar pattern of seminoma (Figure 8). Thirteen tumors with these features were recently reported, ${ }^{7}$ the majority of the tumors being initially misdiagnosed as seminoma because of the overlap in patterns of the two neoplasms. These tumors are typically associated with appreciable cytologic atypicality and account for one important aspect of the differential diagnosis of Sertoli cell tumors, a topic now considered.

\section{Differential Diagnosis}

The tubular pattern of the well-differentiated tumors should be diagnostic in the great majority of cases. 
Some tumors with a diffuse pattern of cells with abundant eosinophilic cytoplasm can suggest a Leydig cell tumor but focal true tubular differentiation excludes the latter diagnosis.

Well-differentiated Sertoli cell tumors should be distinguished from foci of immature tubules (Sertoli cell nodules) that are occasionally seen in cryptorchid and less commonly descended testes. These lesions are rarely grossly visible, in contrast to Sertoli cell tumors that usually measure more than $1 \mathrm{~cm}$ and are obvious neoplasms grossly. The solid tubules of the non-neoplastic lesion contain immature Sertoli cells, in occasional cases scattered spermatogonia, and in some cases rounded aggregates of hyaline material that is rarely a feature of a Sertoli cell tumor. The differential with adenomatoid tumor is considered in the contribution on mesothelial lesions in males.

Confusion of malignant Sertoli cell tumors with a seminoma-like low-power pattern and seminoma may be a clinically consequential error. ${ }^{7}$ This issue was first highlighted decades ago when Collins and Symington ${ }^{11}$ described, in their paper on Sertoli cell tumors, 'sheets of clear cells in which the distinction from seminoma was difficult'. Helpful findings in the recent series that have re-emphasized this problem are as follows. For the most part, the clinical background is of no aid although it is of note that five of the 13 seminoma-like Sertoli cell tumors occurred in men over 55 years, when typical seminoma is uncommon and this exemplifies the important point that in men over 50 years a testicular tumor is more likely to be of nongerm cell type than is the case for younger men. Grossly, the Sertoli cell tumors are more often firm with some yellow aspects to their sectioned surface but ultimately microscopic differences are crucial. Although the inflammatory cell infiltrate, with even germinal center formation in a few cases, is one of the confusing issues it is also pertinent to note that this infiltrate more typically contains many plasma cells than does the infiltrate in seminomas. Areas of definite tubular differentiation are of course helpful but were prominent in only three of the 13 seminoma-like Sertoli cell tumors being considered here. Cytologic differences between the cells and the two tumors are most important. Nine of the Sertoli cell tumors had distinct cytoplasmic vacuoles, often helpful clues to the diagnosis of Sertoli cell tumor, even on low-power examination. Most importantly, the nuclei of the Sertoli cell tumors were generally smaller with less prominent nucleoli than those of seminoma and had rounded (Figure 9) rather than 'squared-off' nuclear contours, the latter being typical of seminoma nuclei. Five Sertoli cell tumors did, however, have prominent nucleoli indicating the overlap that can make this a difficult interpretation. It should also be noted that both tumors may have cytoplasmic glycogen. A granulomatous infiltrate, if present, would favor seminoma not having been seen in a Sertoli cell tumor to our knowledge, as would intratubular germ cell neoplasia in adjacent seminiferous tubules. The above differences and immunohistochemical ones (Figure 10) (see below) will enable the two neoplasms to be distinguished provided the pathologist is aware of this pitfall.

\section{Behavior}

Most well-differentiated tumors are clinically benign but a rare neoplasm that has relatively bland microscopic features metastasizes. Large size $(5 \mathrm{~cm}$ or greater) and conventionally worrisome features such as necrosis, nuclear atypicality, vascular invasion, and a brisk mitotic rate (more than 5 per 10 high-power fields) increase the likelihood of a clinically malignant course. In one series five of seven malignant tumors had at least three of the five features just noted. ${ }^{6}$ The prognostic importance of size is reinforced by the fact that 11 of 14 malignant tumors in the literature whose size was recorded were more than $5 \mathrm{~cm} .{ }^{9}$ Tumors with a more or less diffuse, seminoma-like appearance appear to have a greater tendency to metastasize even when less than $5 \mathrm{~cm}$. In the series that included only tumors of this type, four tumors that were $3 \mathrm{~cm}$ or less metastasized. ${ }^{7}$ However, all of them had necrosis and highgrade cytologic atypia and two of them exhibited vascular space invasion. There is some evidence in the literature to suggest that gynecomastia is seen more often in clinically malignant tumors.

\section{Large Cell Calcifying Sertoli Cell Tumor}

This tumor ${ }^{12}$ has occurred at an average age of 21 years and in approximately one-third of them various unusual clinical findings are present as described in some of the initially reported cases and later expounded on by the 2004 Maude Abbott lecturer, Dr JA Carney. ${ }^{13}$ On gross examination, these tumors usually have no characteristic gross features

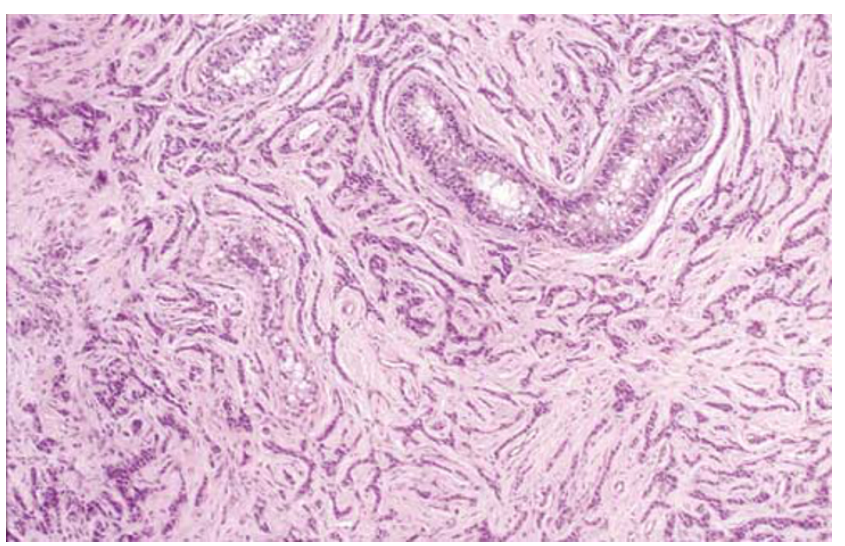

Figure 11 Sclerosing Sertoli cell tumor of testis. The marked sclerosis separates the tumor cells into thin cords. 


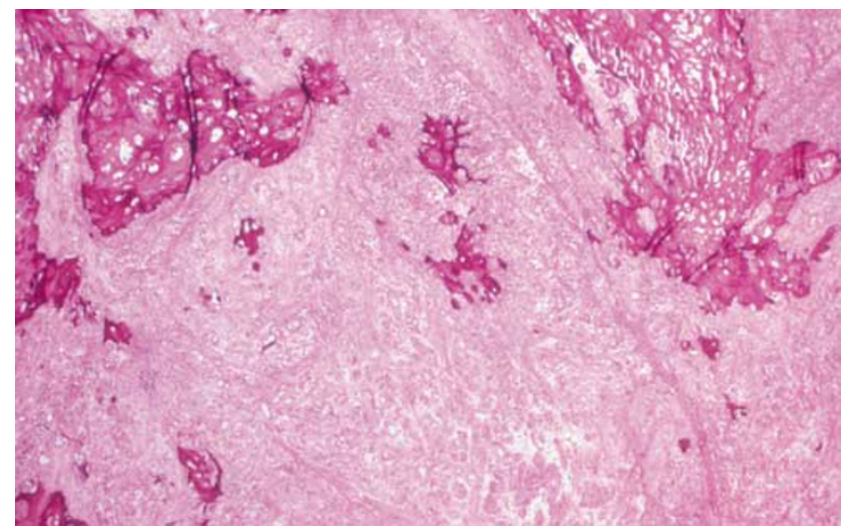

Figure 12 Large cell calcifying Sertoli cell tumor of testis. There are calcified plaques separating the tumor cells that have abundant eosinophilic cytoplasm.

unless a gritty nature can be appreciated due to the calcification. In contrast to most other sex cord tumors, they are bilateral in about $20 \%$ of the cases, this feature almost always being seen in patients with Carney's syndrome. On microscopic examination (Figure 12), the neoplastic cells have various patterns, sheets, nests, ribbons or cords, and small clusters but at least focally solid tubules are present and often conspicuous. They may be multifocal. The tumor cells are large with abundant eosinophilic cytoplasm. The other defining microscopic feature is the presence of calcification, which is sometimes massive. In contrast to other sex cord tumors, intratubular growth is relatively frequent. The majority of the neoplasms have bland cytologic features but rare neoplasms are locally infiltrative, sometimes with atypical cytologic features and some of these neoplasms have been clinically malignant. ${ }^{14}$ Rare testicular Sertoli cell tumors resemble this tumor except that they lack the defining calcification.

\section{Testicular Tumors in Peutz-Jeghers Syndrome}

Although the exact placement of some testicular lesions in patients with Peutz-Jeghers syndrome is not clear, they are almost always more closely related to Sertoli cell tumors than granulosa cell tumors. ${ }^{15,16}$ Enigmatically they also focally may have an annular tubular pattern similar to that in the ovarian sex cord tumor with annular tubules, which also has an association with Peutz-Jeghers syndrome (see below). The testicular lesions often also have some features reminiscent of the large cell calcifying Sertoli cell tumor, albeit lacking calcification. When Ulbright et $a l^{5}$ reviewed the topic relatively recently four of the seven cases analyzable at that time resembled the large cell calcifying Sertoli cell tumor, two the sex cord tumor with annular tubules, and one a Sertoli cell tumor, not otherwise specified. Some lesions have morphology

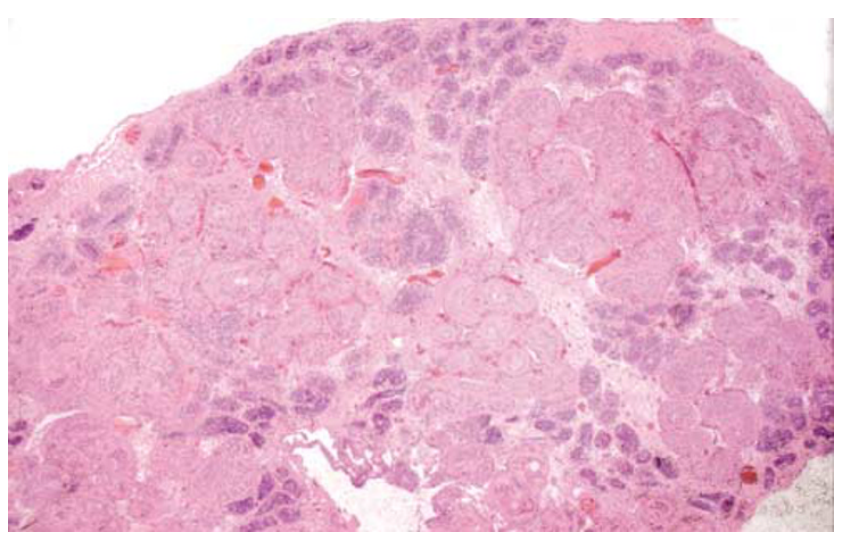

Figure 13 Testicular lesion in Peutz-Jeghers syndrome. There is a multifocal abnormal proliferation of tubules.

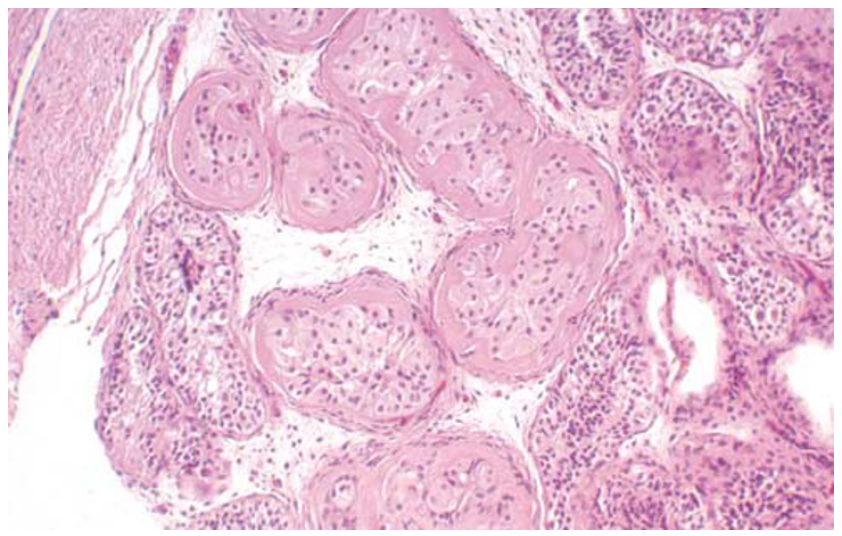

Figure 14 Testicular lesion in Peutz-Jeghers syndrome. There is prominent peritubular hyalinization and the tubules are filled with Sertoli cells that have abundant eosinophilic cytoplasm.

intermediate to that of the first two subtypes of Sertoli cell tumor just listed. From the clinical viewpoint, the lesions are often estrogenic; in one series all six patients had gynecomastia. ${ }^{16}$ The lesions are typically small and sometimes are discovered only on ultrasonography. The growth is often multifocal, typically intratubular and hyalinization may be striking (Figures 13 and 14). ${ }^{15,16}$ Conservative management is indicated on the current evidence.

\section{Ovarian Sertoli Cell Tumors}

When Dr Robert Scully and I reviewed this topic in 1984 , we were only able to identify a small number of cases that passed close scrutiny. ${ }^{17}$ Stringent criteria were used at that time because of our awareness that many other neoplasms of diverse types can closely simulate Sertoli cell tumors. The advent of immunohistochemistry (reviewed below) has now made it easier to categorize problematic tubular tumors as Sertoli cell tumors and we have 
just completed a study of a larger series of cases. ${ }^{18}$ Given the above comment on testicular abnormalities in Peutz-Jeghers syndrome, it is of note that six of our patients had that syndrome. These tumors did not have the features of the sex cord tumor with annular tubules that we separately categorize, ${ }^{19}$ an approach others disagree with. ${ }^{20}$ Some Sertoli cell tumors have produced estrogen and Sertoli cell tumors have accounted for three of the small number of ovarian tumors associated with renin production. ${ }^{4}$ Sertoli cell tumors that are welldifferentiated tumors are almost always benign whereas tumors with atypical features have a malignant potential.

The predominant microscopic pattern of ovarian Sertoli cell tumors, like those in the testis, is tubular (Figures 15-17) but other patterns, particularly cordlike and diffuse, are common. Rarely, as in Sertoli cell tumors of the testis, there is an alveolar pattern (Figure 18) that may suggest dysgerminoma on low

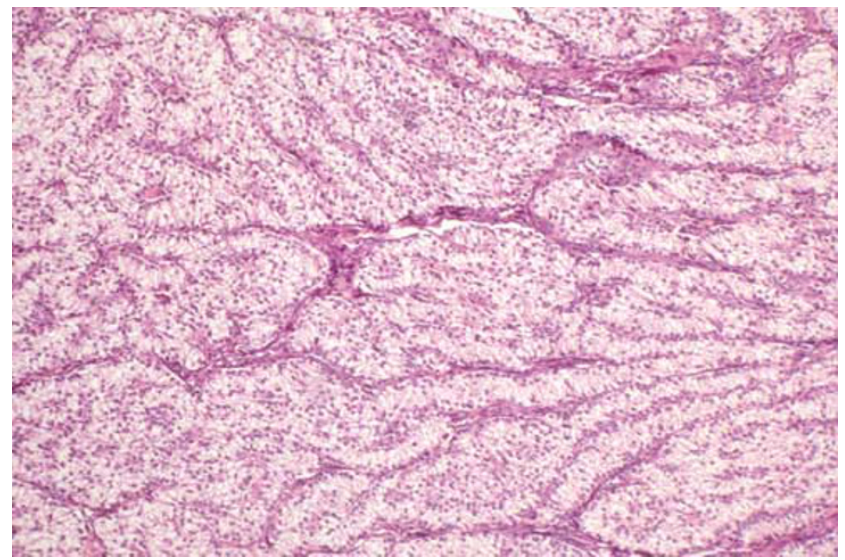

Figure 15 Lipid-rich Sertoli cell tumor of ovary. This patient had Peutz-Jeghers syndrome.

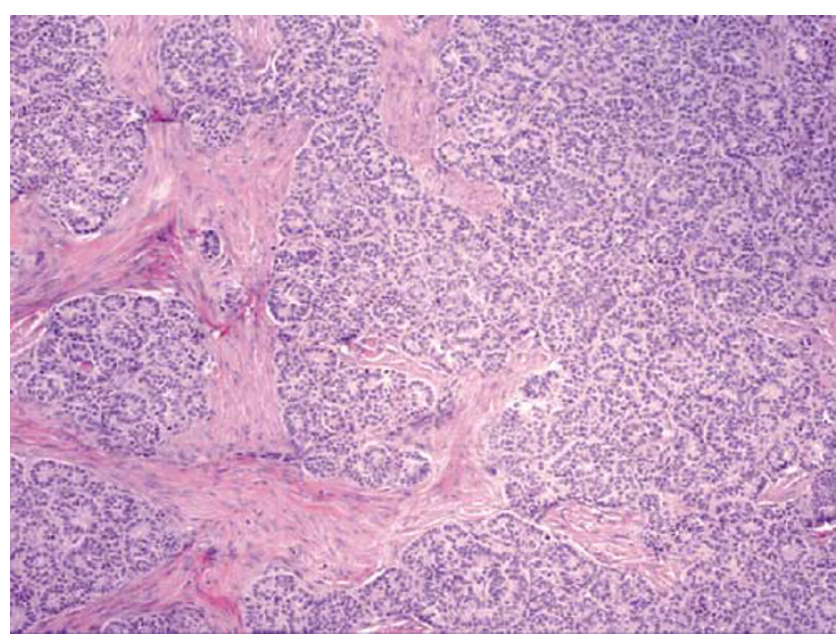

Figure 16 Sertoli cell tumor of ovary. Lobular aggregates of hollow tubules are separated by fibrous stroma.

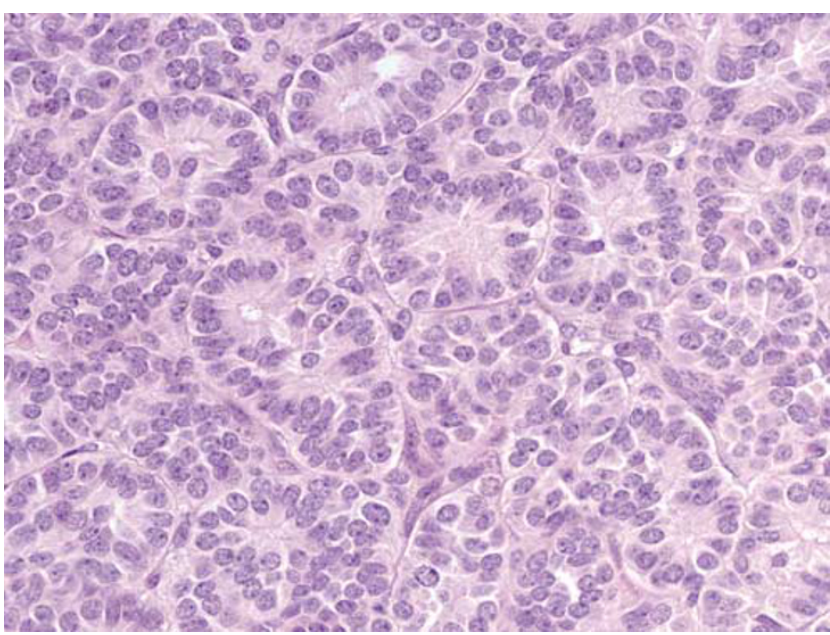

Figure 17 Sertoli cell tumor of ovary. High-power view shows typical tubules from a well-differentiated neoplasm.

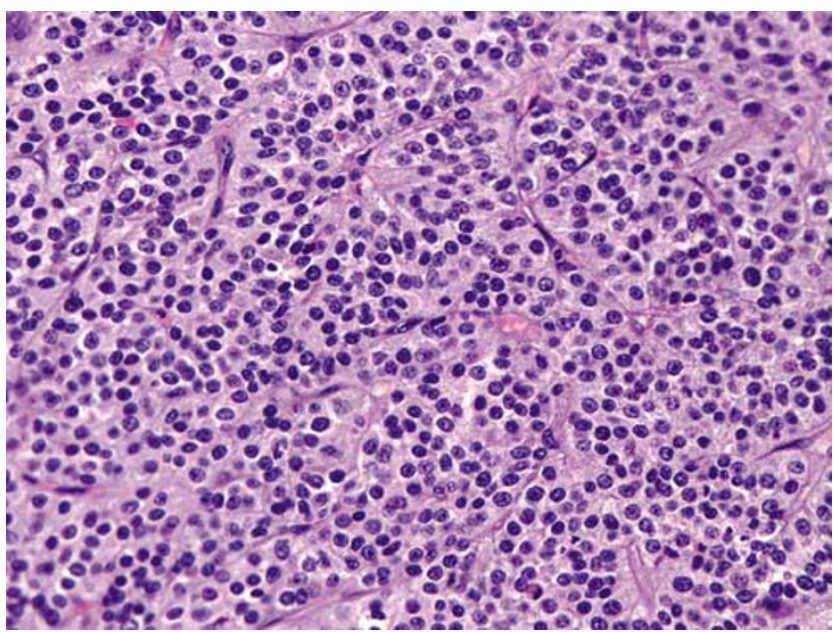

Figure 18 Sertoli cell tumor of ovary. There is a vaguely alveolar arrangement of the neoplastic cells. This may impart a superficial resemblance to dysgerminoma.

power. Also rare is a retiform pattern, which is much more typical of SLCTs (see below). These tumors may have an abundant stroma as in Sertoli cell tumors of the testis but it is typically not as striking. Some ovarian tumors share with the testicular tumors a content of cells with conspicuous eosinophilic cytoplasm and occasionally the cytoplasm is strikingly vacuolated. Most of the tumors are stage I.

\section{Ovarian Tumors in Peutz-Jeghers Syndrome}

A distinctive pattern of ovarian neoplasia is exemplified by the neoplasm designated sex cord tumor with annular tubules (Figure 19). ${ }^{19}$ The tubular pattern has been taken by some ${ }^{20}$ to indicate that these tumors should be grouped with Sertoli cell tumors, and the cells forming the tubules are probably closer to Sertoli cells than granulosa cells 
S88

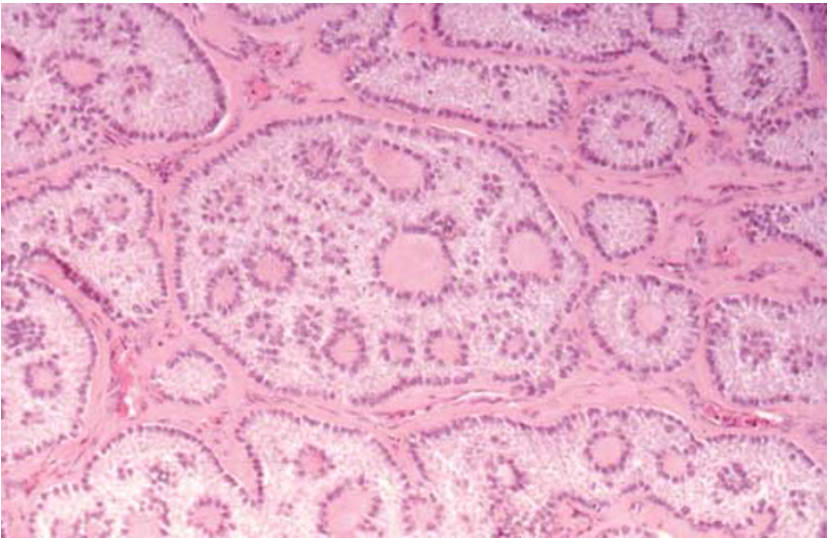

Figure 19 Sex cord tumor with annular tubules. This ovarian tumor was from a patient who did not have Peutz-Jeghers syndrome. It shows the typical antipodal arrangement of the cells lining the tubules, which encircle hyaline basement membranelike material.

as the distinctive ultrastructural finding of Sertoli cells, Charcot-Bottcher crystals, has been found in some cases. The distinctive features of the tumor in our opinion merit separate categorization, although this is a matter of debate. Further rationale for separate classification is provided by the association of one-third of these lesions with Peutz-Jeghers syndrome and that tumors not associated with this syndrome have distinctive features such as an occasional association with progesterone production and a higher than usual frequency of lymph node spread, when compared to other sex cord tumors. When seen in cases of the syndrome, the lesion is typically small, bilateral, and calcified whereas those unassociated with the syndrome form unilateral adnexal masses.

Rarely patients with the Peutz-Jeghers syndrome have Sertoli cell tumors either of the lipid-rich cell type (Figure 15) ) $^{18,21}$ or sometimes of the not otherwise specified type, a few in the latter group being characterized by cells with abundant oxyphilic cytoplasm. ${ }^{22}$

Gonadal pathology in the Peutz-Jeghers syndrome is similar inasmuch as each gonad has the propensity to develop peculiar lesions that although neoplastic are clinically benign and fall more on the Sertoli than the granulosa side of the fence. However, despite similarities, there are differences inasmuch as the testicular lesions, although having focal features of the sex cord tumor with annular tubules, often have hybrid features as noted above.

\section{Sertoli-Leydig cell tumors}

One of the most striking exceptions to the frequent parallelism that exists between ovarian and testicular sex cord tumors is the SLCT because testicular tumors with this morphology are exceptionally rare. To this day, the great majority of the valid cases in the literature are those described by $\mathrm{Dr}$ Teilum. ${ }^{2}$ When reviewing this topic for the fascicle on the testis, obtaining cases for documentation was difficult and the great rarity of testicular tumors in this group, which by definition resemble the ovarian tumors considered below, precludes detailed comment. Although rare well, intermediate, and poorly differentiated tumors occur, there is not a typical case in the literature of testicular Sertoli-Leydig cell tumor with heterologous elements or a striking retiform pattern. The rest of this consideration of these tumors is devoted to the much more common, but still rare, ovarian examples.

\section{Ovarian SLCTs}

The subdivision of ovarian SLCTs used today is fundamentally that of Meyer ${ }^{1}$ but more recently it has become evident that tumors with a retiform component have sufficiently characteristic clinical and pathologic features to merit separate classification as a distinct subtype. ${ }^{23}$ It should be noted that there is considerable overlap between the various categories of SLCT. For example, many tumors have foci that are of intermediate differentiation and other areas that are poorly differentiated tumors and each of those subtypes can have a retiform pattern, heterologous elements, or both. Well-differentiated tumors, however, are almost always pure without heterologous or retiform components. There has been considerable interest in SLCTs in the last two decades with the publication of several large studies. ${ }^{4}$ Only the two most morphologically intriguing groups of SLCTs are considered in detail after a few general remarks about the well, intermediate, and poorly differentiated groups emphasizing some important pitfalls.

The differential diagnosis of SLCTs as a whole exemplifies a point made earlier, namely that although these tumors are rare, they often come up in the differential diagnosis of ovarian tumors because of the extent to which their various patterns overlap with those of many other ovarian tumors. This overlap in patterns has been reviewed in detail elsewhere ${ }^{24}$ and only a few comments will be made here. A particularly helpful finding in the $10 \%$ of tumors that are in the well-differentiated category is the extensive component of Leydig cells in the stroma. Although this finding can be mimicked to some degree by the diverse ovarian tubular tumors that can have a luteinized stroma, the consistent nature of the tubular differentiation and extent of the Leydig cell component is a clue to the diagnosis of SLCT and this can be confirmed by immunohistochemistry. The single most common pattern of the tumors of intermediate differentiation is a striking nodular growth (Figure 20) with large cellular 'blue nodules' being intersected by a stroma that is often edematous. Within the cellular nodules dark blue Sertoli cells are admixed with Leydig cells, the latter 


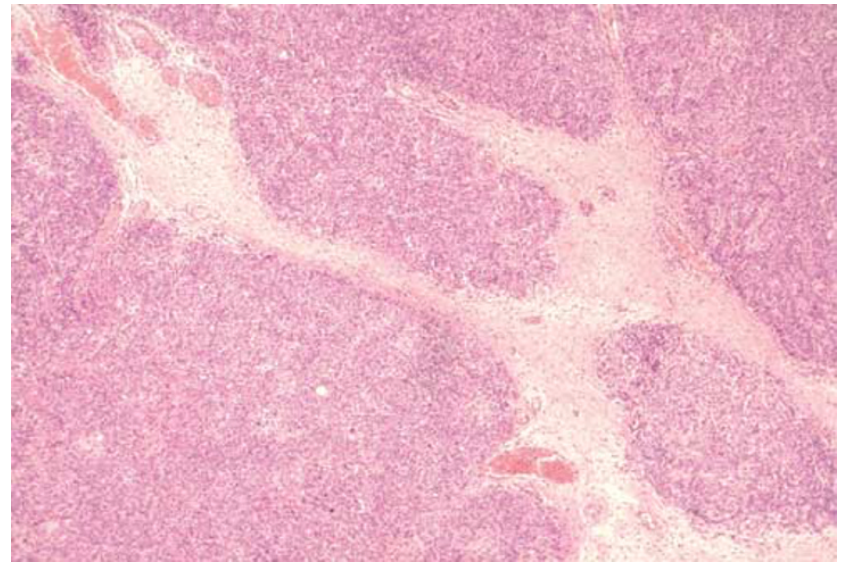

Figure 20 SLCT of ovary of intermediate differentiation. Large lobules composed predominantly of darkly staining Sertoli cells impart a picture seen in many tumors of intermediate differentiation.

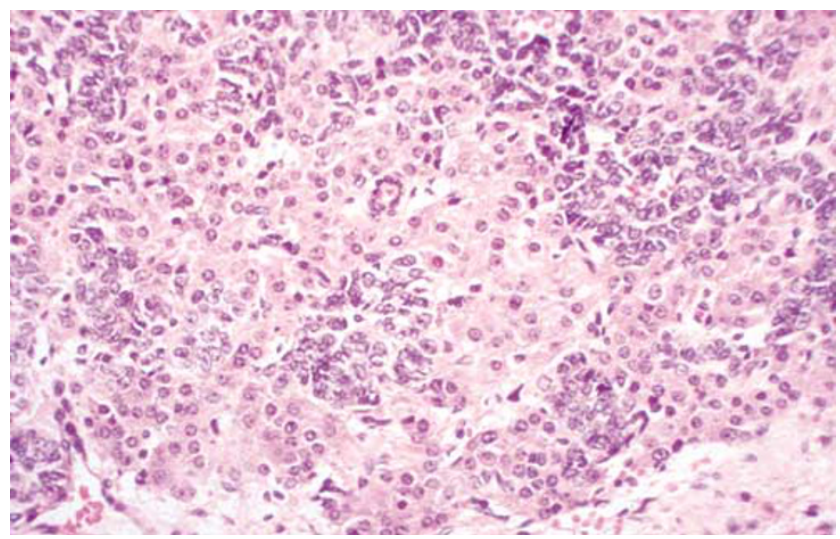

Figure 21 SLCT of ovary of intermediate differentiation. Highpower view of a cellular lobule shows a jumbled admixture of Sertoli cells and Leydig cells, the latter having abundant eosinophilic cytoplasm.

being much less common and often only identifiable on careful high-power scrutiny (Figure 21). Perhaps the single most treacherous pitfall in differential diagnosis in these cases is with a Krukenberg tumor that may have a similar low-power appearance because of stromal edema and small malignant cells that do not always have an overt signet-ring cell morphology, although cells of the latter type, by definition, are identified focally. In the differential diagnosis with Krukenberg tumor, the presence of tubules in the latter neoplasm, as mentioned in the contribution of Dr Prat, may be a particularly problematic finding. Occasional tumors have microcysts (Figure 22) that we have seen cause confusion with yolk sac tumor. Poorly differentiated tumors may be hard to distinguish from pure sarcomas and the diagnosis of poorly differentiated SLCT should always be strongly considered when the diagnosis of a pure sarcoma is being entertained. Most otherwise featureless poorly differentiated SLCTs have small

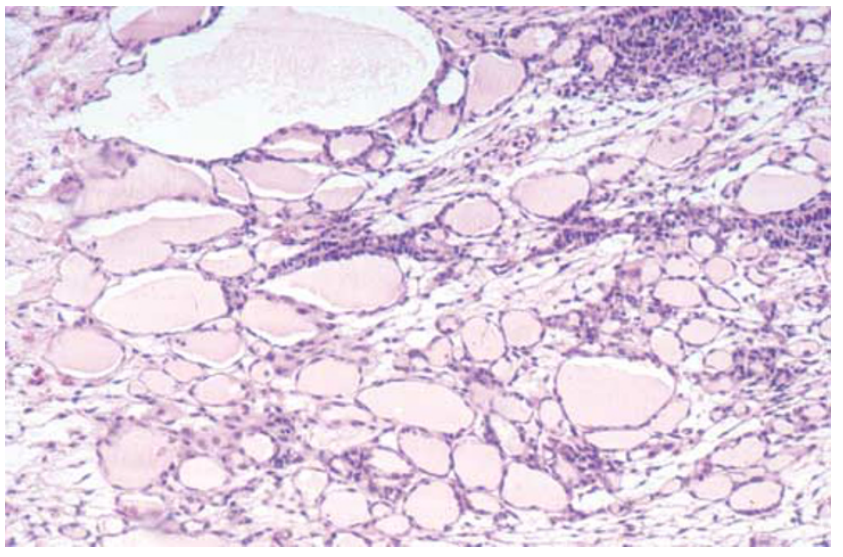

Figure 22 SLCT of ovary of intermediate differentiation. There is a peculiar microcystic pattern that could be misconstrued as yolk sac tumor.

diagnostic areas composed of clusters of dark blue Sertoli cells and some cells that are consistent with Leydig cells or their precursors that will confirm the diagnosis.

Like other sex cord stromal tumors of the ovary (but not to any appreciable degree in the testis), occasional SLCTs contain markedly bizarre nuclei. ${ }^{25}$ When these are a focal finding in an otherwise typical neoplasm, they generally do not cause problems, but sometimes a significant component of the tumor has cells with irregular, hyperchromatic, lobulated nuclei. Awareness of this phenomenon and the presence of focal areas of typical SLCT should enable the misdiagnosis of a more malignant tumor to be avoided.

A phenomenon that is obviously unique to the ovary is the spectrum of change seen in SLCTs from pregnant patients. ${ }^{26}$ The change that causes most difficulty is marked intercellular edema often resulting in large areas with a nonspecific, loose appearance (Figure 23) that may be confused with the reticular pattern of a yolk sac tumor. Occasionally sheet-like aggregates of Leydig cells may obscure the Sertoli cell component and potentially lead to the misdiagnosis of a Leydig cell tumor.

\section{Heterologous SLCTs}

These tumors, which account for approximately $20 \%$ of SLCTs, do not differ significantly in their clinical presentation from otherwise similar tumors without a heterologous component. The only noteworthy gross feature is that some of them are predominantly cystic. ${ }^{27}$ On microscopic examination, the heterologous elements are of two basic types, endodermal elements characterized by gastrointestinal-type epithelium (Figure 24) and mesenchymal elements, immature skeletal muscle or cartilage. ${ }^{27,28}$ The presence of these tissues complicates the already wide range of appearances of 
S90

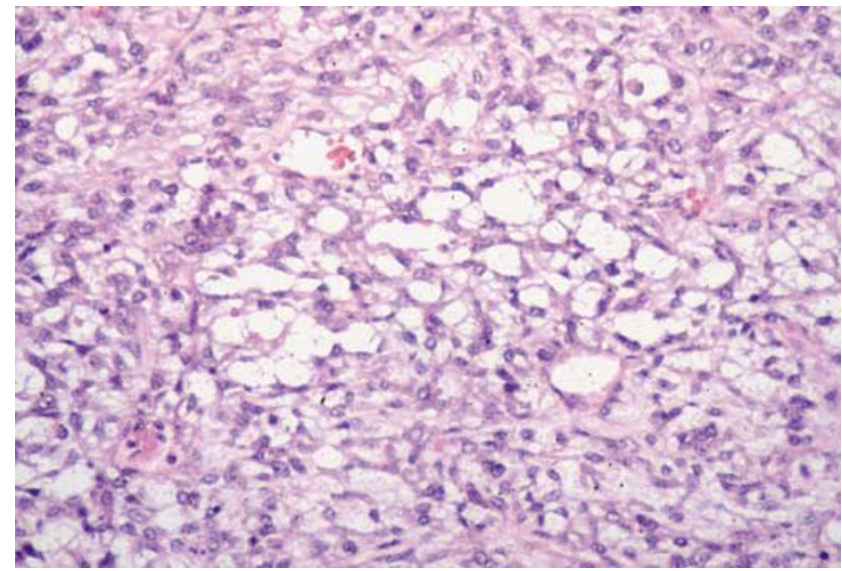

Figure 23 SLCT of ovary from a pregnant patient. Intercellular edema has resulted in an appearance that may be misconstrued as the reticular pattern of yolk sac tumor.

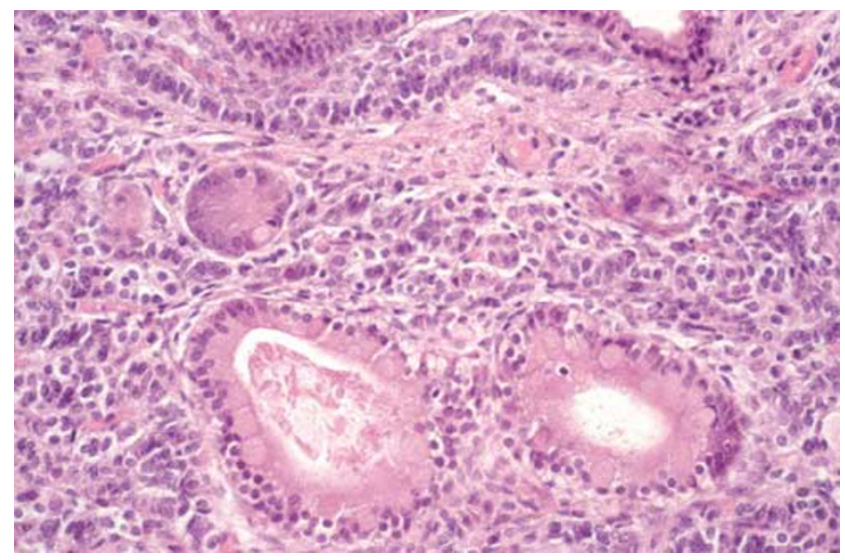

Figure 24 SLCT of ovary with heterologous elements. Mucinous glands are separated by many Sertoli cells.

SLCTs. The amount of mucinous epithelium in the tumors, which are usually of intermediate differentiation, varies from one or a few microscopic foci to numerous glands and cysts. The gastrointestinaltype epithelium typically contains goblet cells and often argentaffin cells. The latter cells occasionally give rise to foci of carcinoid (Figure 25) that are typically small, usually insular carcinoid but sometimes mucinous carcinoid. The presence of endodermal elements, present in about $20 \%$ of SLCTs, does not alter the prognosis of these tumors. The mesenchymal heterologous elements (Figure 26), present in about $5 \%$ of SLCTs, are typically seen in poorly differentiated tumors and have a poor prognosis. ${ }^{28}$

\section{Retiform SLCTs}

Despite the fact that retiform foci, defined as areas with architectural and cytological features simulat-

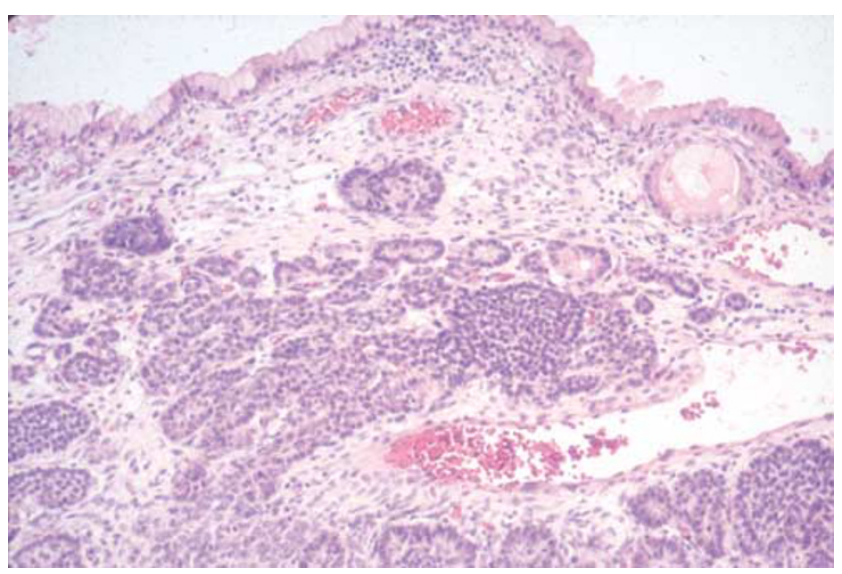

Figure 25 SLCT of ovary with heterologous elements. Insular foci of carcinoid occupy much of the bottom half of the illustration; mucinous epithelium is seen at the top.

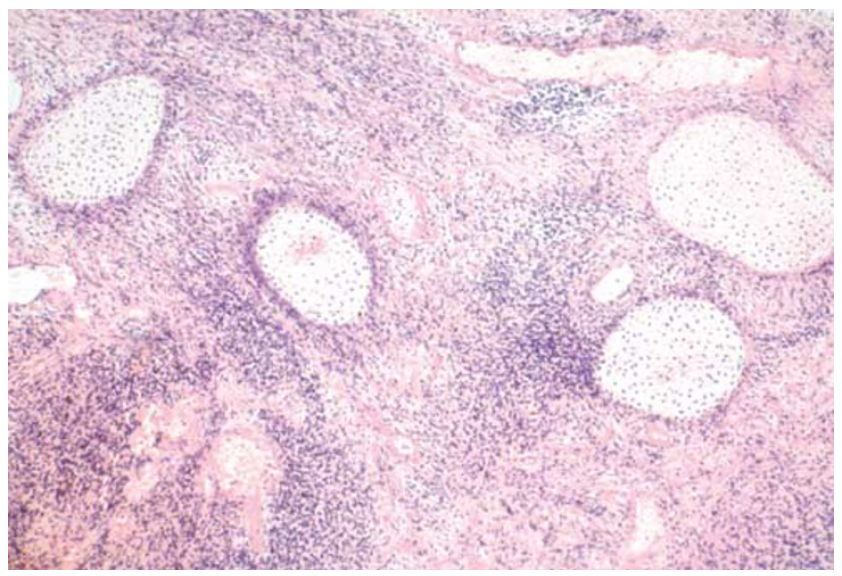

Figure 26 SLCT of ovary with heterologous elements. Islands of fetal-type cartilage are present on the background of a cellular mesenchymal component.

ing those of the rete testis, are present in from 10 to $15 \%$ of SLCTs, it is only recently that this pattern has received significant attention. ${ }^{23,29-31}$ These tumors differ clinically from usual SLCTs in two important respects. They occur in a younger age group (average age 15 vs 25 years for SLCTs as a group) and are less often androgenic, such manifestations being present in only approximately $25 \%$ of the cases as opposed to $50 \%$ for SLCTs as a group. This is important as the presence of androgenic manifestations sometimes directs the pathologist toward the correct diagnosis of SLCT and if the pattern of the tumor, specifically a retiform one, is not a familiar one and there are no androgenic manifestations, the likelihood of a misdiagnosis is increased. Occasional retiform SLCTs and indeed SLCTs of other types may be associated with elevated serum levels of alpha-fetoprotein, ${ }^{32,33}$ a finding that may be confusing as it usually suggests a yolk sac tumor when a young female has an ovarian neoplasm. 


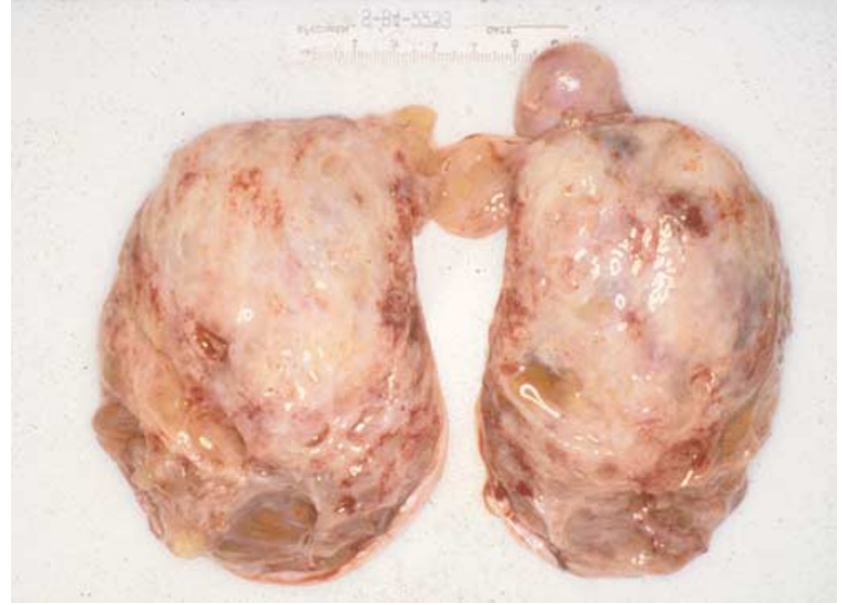

Figure 27 SLCT of ovary with retiform pattern. This neoplasm had a soft spongy sectioned surface as is characteristic of many such neoplasms.

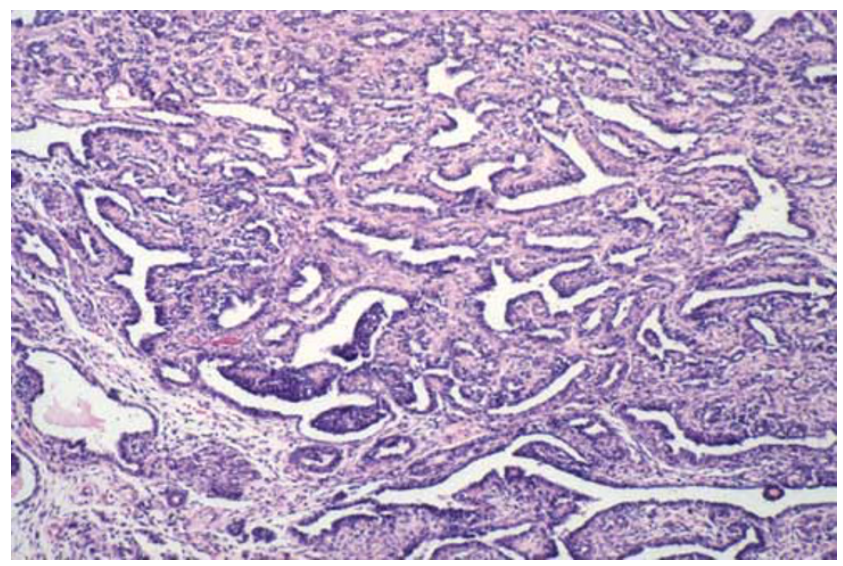

Figure 28 SLCT of ovary with retiform pattern. Irregular clefts and rare papillae are evident.

On gross evaluation, these tumors tend to be larger and more often cystic than SLCTs in general, often with large intracystic polypoid projections, a finding that has occasionally caused these tumors to be likened to a hydatidiform mole. In other cases they are not cystic, or minimally so, but may be soft and spongy an appearance that should suggest the diagnosis (Figure 27). Despite these two gross aspects that are suggestive of the diagnosis the gross appearance is not distinctive in some cases. On microscopic examination there are typically elongated, often slit-like, branching tubules (Figure 28) that may focally or extensively be cystically dilated. In many cases papillae (Figure 29) or polyps project into the tubules and cysts. The papillae may be rounded with a hyalinized eosinophilic core, or may be cellular. Large edematous polypoid structures correspond to the grossly visible polyps. Retiform SLCTs are apt to be confused microscopically with serous tumors (Figure 29) and we have also seen cases in which retiform tubules in the background of

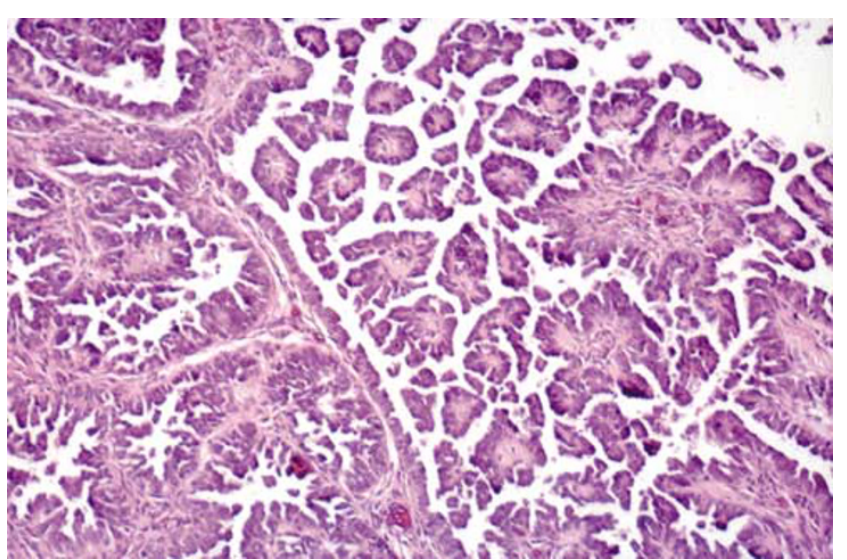

Figure 29 SLCT of ovary with retiform pattern. Small papillae are reminiscent of what is seen in serous papillary tumors.

cellular mesenchymal tissue have led to the misdiagnosis of a carcinosarcoma. The additional presence of heterologous elements, such as cartilage, may enhance the resemblance to a carcinosarcoma. The diagnosis of carcinosarcoma, serous borderline tumor or serous carcinoma should be rendered in a patient in the first two decades only after the diagnosis of a retiform SLCT has been excluded. Another rare finding in SLCTs is hepatoid cells. ${ }^{32,34}$

\section{Granulosa cell tumors}

The now familiar subclassification into adult and juvenile types is followed here although it is important to note that these are terms of convenience to denote the usual age group in which each type occurs but there are exceptions to each situation.

These tumors, like SLCTs, are much more common in the ovary than in the testis, although testicular granulosa cell tumors, both of the adult type and juvenile types, are more common than testicular SLCTs. In the ovary, the adult form is much more common than the juvenile form, whereas in the testis, at least on the basis of material we see, the juvenile form is more common. The juvenile neoplasm in the testis has a tendency to occur in very young patients in the first 6 months when the ovarian juvenile granulosa cell tumor is uncommon, in females these tumors are more uniformly distributed throughout the first two decades. The tumors are morphologically similar in both gonads with one exception that will be noted.

\section{Ovarian Adult Granulosa Cell Tumor}

The clinicopathologic features of these neoplasms are well known and only a few noteworthy observations are made here. Although these neoplasms may be seen at any age, there is a striking peak in the late 
reproductive and early postmenopausal years such that the diagnosis should always be considered, assuming morphology remotely compatible with the diagnosis, when an ovarian tumor is encountered in a person between 45 and 55 years of age. This is particularly so when any of the three usual gross appearances are present: solid and cystic with hemorrhage within cysts, solid and yellow, or cystic, either multilocular or unilocular. The time-honored association with hyperestrinism and various menstrual abnormalities, and in postmenopausal patients, postmenopausal bleeding, and in some cases well-differentiated endometrial carcinomas of endometrioid type need no elaboration here.

From the microscopic perspective, in recent years we have attempted to decrease the emphasis placed in the older literature on Call-Exner bodies. The latter are certainly helpful findings provided care is taken not to confuse them with other small acinar formations but in many granulosa cell tumors they are absent, a negative finding that occasionally makes the pathologist reluctant to make the diagnosis. In our experience, the most common pattern of these neoplasms is a more or less diffuse growth, at least on initial low-power scrutiny, although usually subtle cords and other epithelial formations become apparent, at least focally, on more detailed evaluation. The pale grooved nuclei of the adult granulosa cell tumor, although again an important finding, have perhaps been somewhat overemphasized inasmuch as other neoplasms may have pale nuclei with grooves. Furthermore, some granulosa cell tumors have nuclei that are somewhat hyperchromatic and grooves may be inconspicuous. Additionally, although brisk mitotic activity in a putative granulosa cell tumor should always make the pathologist consider other options valid adult granulosa cell tumors may have brisk mitotic activity on occasion. A careful consideration of the overall morphology, awareness of the features of the various lesions that may be in the differential diagnosis, and consideration of the clinical and gross features should make the diagnosis relatively straightforward most of the time. Granulosa cell tumors rarely contain Leydig cells and, like SLCTs, hepatoid cells. ${ }^{35}$ The role of immunohistochemistry is discussed below although it is worthy of mention here that granulosa cell tumors may be inhibin negative, a finding that should not necessarily shake the confidence of the pathologist.

\section{Ovarian Juvenile Granulosa Cell Tumor}

Although much more recently recognized than the adult neoplasm, this tumor is now firmly established as a distinctive subtype of ovarian sex cord tumor. ${ }^{36-38}$ The solid and follicular pattern (with follicles of irregular size and shape) (Figure 30), luteinization of the tumor cells, and immaturity of nuclei with an often brisk mitotic rate distinguish

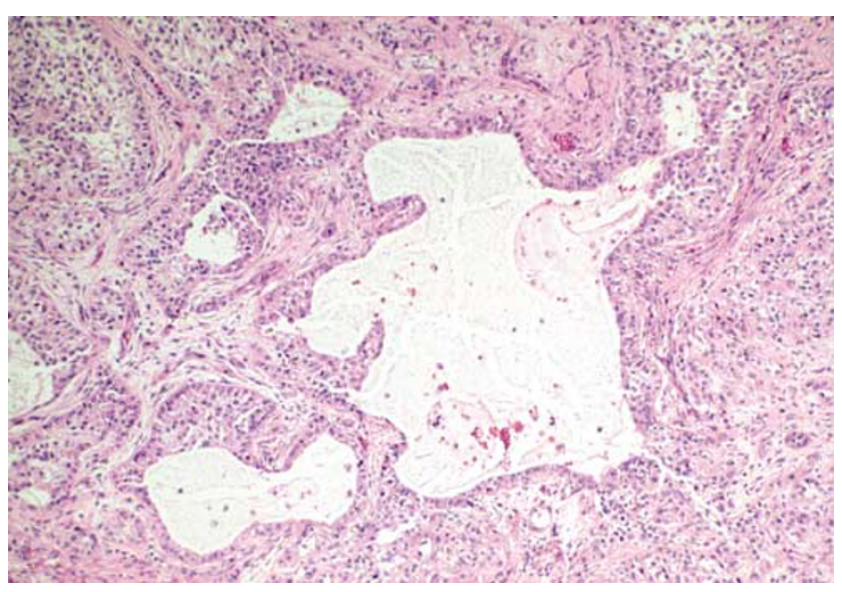

Figure 30 Juvenile granulosa cell tumor of ovary. The follicles are irregular in size and shape.

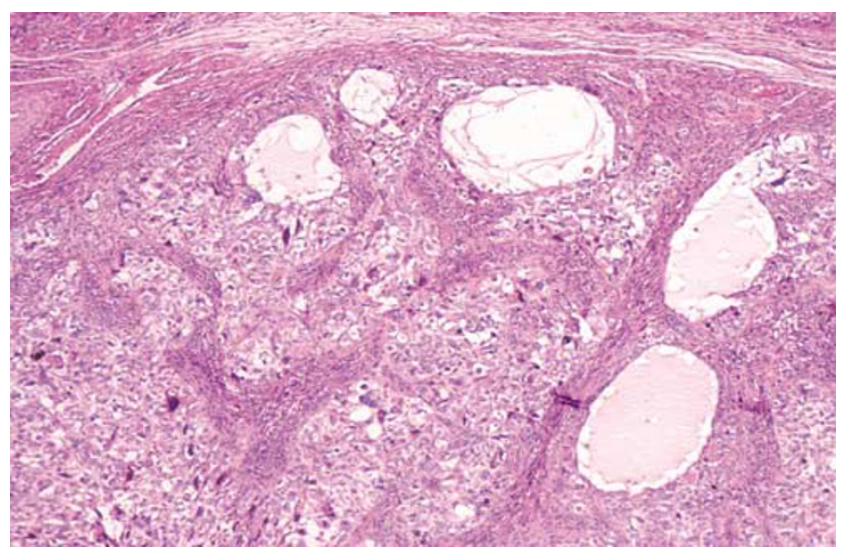

Figure 31 Juvenile granulosa cell tumor of ovary. There is prominent nuclear atypia, which can lead to the misdiagnosis of a more highly malignant form of ovarian neoplasia.

the tumor from most adult granulosa cell tumors. Occasional adult tumors have abundant (luteinized) cytoplasm but lack the architectural features of the juvenile variant. ${ }^{39}$ Perhaps the most important problematic finding in the juvenile neoplasm is marked nuclear pleomorphism in almost $15 \%$ of the cases (Figure 31). ${ }^{37}$ For stage I tumors, this is not proven to have adverse prognostic significance, although it reasonably causes concern, particularly when striking. Enigmatically, there is often more nuclear pleomorphism in these tumors than in tumors that are inherently more malignant such as the yolk sac tumor.

\section{Testicular Adult Granulosa Cell Tumor}

Less than two dozen adult granulosa cell tumors are well documented. ${ }^{40-43}$ They typically occur in the middle years of life. Of the reported cases, $20 \%$ have been associated with gynecomastia. The tumors 
have no distinctive gross features and their microscopic features are identical to their ovarian counterparts. Four patients with this tumor have had metastases. Jimenez-Quintero et $a l^{41}$ considered size $>7 \mathrm{~cm}$, vascular or lymphatic invasion, and hemorrhage or necrosis somewhat predictive of spread.

\section{Testicular Juvenile Granulosa Cell Tumor}

This is the most common neoplasm of the testis in the first 6 months of life. ${ }^{44-49}$ The better known yolk sac tumor of the testis of young boys peaks after 6 months of age. ${ }^{8}$ The tumors are uncommon in older children and are exceptionally rare in adults. Occasional juvenile granulosa cell tumors have occurred in undescended testes of infants with intersexual disorders. ${ }^{50}$ All the reported examples of this tumor have been benign.

The tumors range up to $6 \mathrm{~cm}$ in diameter. They may be solid, often with a nodular yellow-orange (Figure 32) or tan-white color, cystic or both; the cysts are thin-walled and contain viscid or gelatinous fluid or clotted blood. In one large series of testicular tumors in children, these tumors were much more often cystic than Sertoli cell tumors. ${ }^{8}$ Microscopic examination reveals follicular or solid patterns or both (Figure 33). The follicles vary from large and round to oval to small and irregular. They typically contain fluid, which may be basophilic or eosinophilic and is mucicarminophilic. In nonfollicular areas, the cells grow in sheets, nodules, and irregular clusters. Hyalinization is sometimes extensive, and in some cases intercellular basophilic mucinous fluid (Figure 34) is conspicuous and may result in a vaguely 'chondroid' appearance. In some cases, the tumor cells are dispersed loosely in the stroma suggesting the reticular pattern of yolk sac tumor. The tumor cells have moderate to large amounts of pale to occasionally eosinophilic cytoplasm and hyperchromatic, round to oval nuclei,

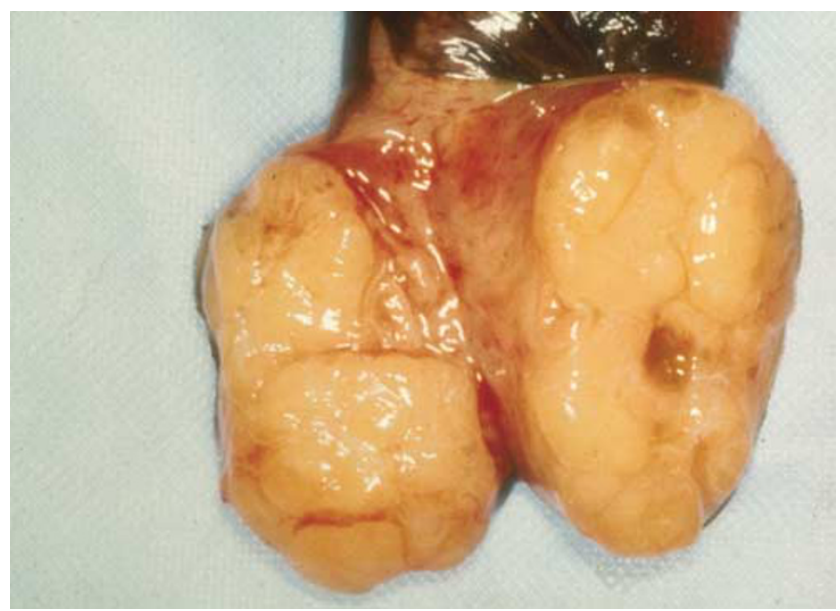

Figure 32 Juvenile granulosa cell tumor of testis. The neoplasm is solid and was soft and yellow.

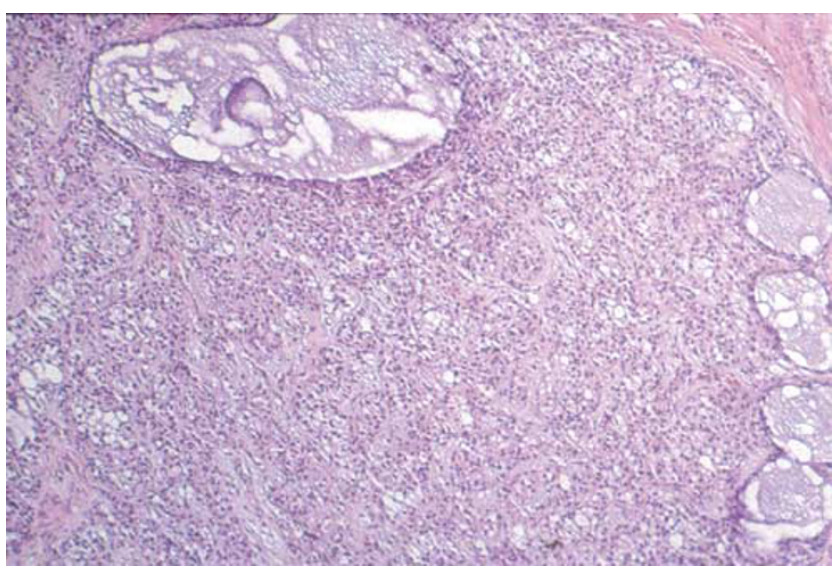

Figure 33 Juvenile granulosa cell tumor of testis. The tumor is composed of a diffuse growth centrally with follicles at the periphery.

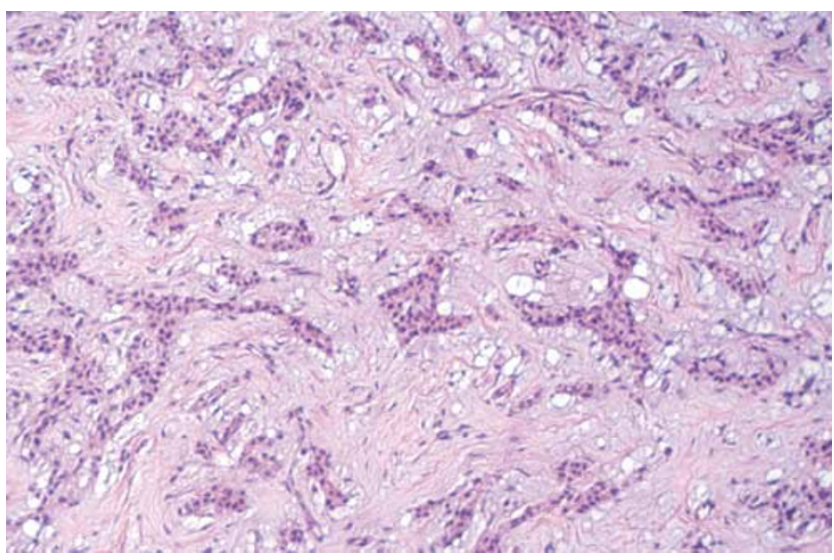

Figure 34 Juvenile granulosa cell tumor of ovary. Islands of tumor cells lie in a basophilic stroma.

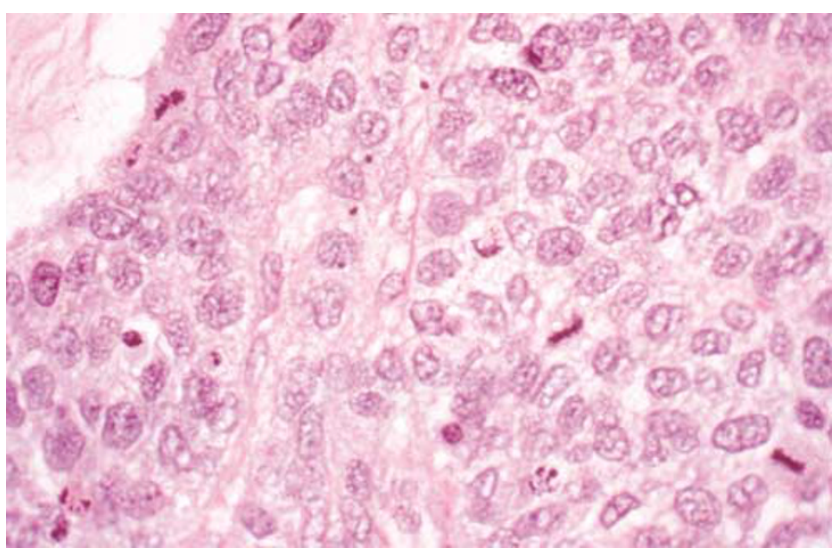

Figure 35 Juvenile granulosa cell tumor of testis. There is brisk mitotic activity.

some of which contain nucleoli. Mitotic activity is usually evident and sometimes prominent (Figure 35).

The juvenile granulosa cell tumor may be misinterpreted as a yolk sac tumor, the other relatively 
frequent testicular tumor of infants, particularly when it exhibits a 'reticular' pattern and brisk mitotic activity. The presence of follicles in most juvenile granulosa cell tumors is helpful as they are not seen in yolk sac tumor provided the cysts of the polyvescicular vitelline pattern of yolk sac tumor are not misidentified as follicles. The absence in juvenile granulosa cell tumor of the various characteristic patterns of yolk sac tumor is obviously helpful. If doubt remains, the lack of immunohistochemical staining for alpha-fetoprotein and likely positivity for inhibin will aid. It should be noted that in very young infants there is normally a physiologically high serum alpha-fetoprotein level so serum determinations of that marker are not helpful. Juvenile granulosa cell tumors are distinguished from the adult form pathologically using the criteria noted above when ovarian tumors are considered.

\section{Sex cord-stromal tumors, unclassified}

In each gonad, occasional tumors are encountered which clearly fall in the sex cord-stromal category but do not lend themselves to placement in the more specific categories, warranting the somewhat unsatisfactory diagnosis of sex cord-stromal tumor unclassified. ${ }^{51}$ Placement in this group happens more frequently in males. In females, a disproportionate number of tumors from pregnant patients are placed in this group ${ }^{26}$ and the peculiar neoplasm that Talerman et $a 5^{52}$ have categorized as 'diffuse nonlobular androblastoma' in our opinion probably is best placed in the unclassified group because it has hybrid features between the granulosa and Sertoli cell families. There is nothing unique about the general clinical profile of the unclassified sex cord-stromal tumors of the ovary and the prognosis of individual cases has to be evaluated using basic principles according to their features. The remainder of this discussion pertains to the more common testicular tumors in this group.

Unclassified sex cord-stromal tumors of the testis occur at all ages. In a registry of tumors in children, almost two-thirds of sex cord tumors were placed in this group ${ }^{53}$ and approximately one-third of the reported tumors have been from children. Gynecomastia is present in about $10 \%$ of the cases. These tumors have no unique gross features.

Microscopically they may be predominantly epithelial, predominantly stromal or have roughly equal proportions of each. Well-differentiated tumors typically contain solid or hollow tubules or cords composed of or lined by cells resembling Sertoli cells. Islands and masses of cells resembling granulosa cells and containing Call-Exner-like bodies may also be present but the overall architectural and cytologic features are, by definition, not typical of granulosa cell tumor. The cytoplasm of cells lining tubules varies from scanty to abundant, and may be eosinophilic, amphophilic, or vacuolated and lipid-laden. Mitotic figures are variably prominent. The stromal component may be densely cellular or acellular and hyalinized. Some stromal cells may have abundant vacuolated or eosinophilic cytoplasm. Poorly differentiated tumors exhibit varying degrees of nuclear pleomorphism and mitotic activity. Diffuse and sarcomatoid patterns are frequent, and in some areas it may be difficult or impossible to distinguish the epithelial and stromal components on routine staining. Reticulum stains may help delineate them. Unclassified sex cordstromal tumors of the testis that are other than very small and cytologically innocuous have to be considered to have a malignant potential; a malignant course seems to be less common in children than in adults. ${ }^{47}$

\section{Sex cord-stromal tumors of the testis with features that result in mimicry of unclassified mixed germ cell sex cord-stromal tumors}

There are three different situations in which the appearance of testicular sex cord-stromal tumors may suggest the rare gonadal tumor, unclassified mixed germ cell sex cord-stromal tumor. The first, and most common, is seen when sex cord-stromal tumors, which are usually slowly growing neoplasms, entrap non-neoplastic germ cells (Figure 36). This phenomenon has only been seen to date with Sertoli-stromal tumors and unclassified tumors, there being four of the former and five of the latter in the paper of Ulbright et $a l^{54}$ that described this phenomenon. These tumors have no special gross or clinical features. In all these cases, the germ cells were interpreted as non-neoplastic because of

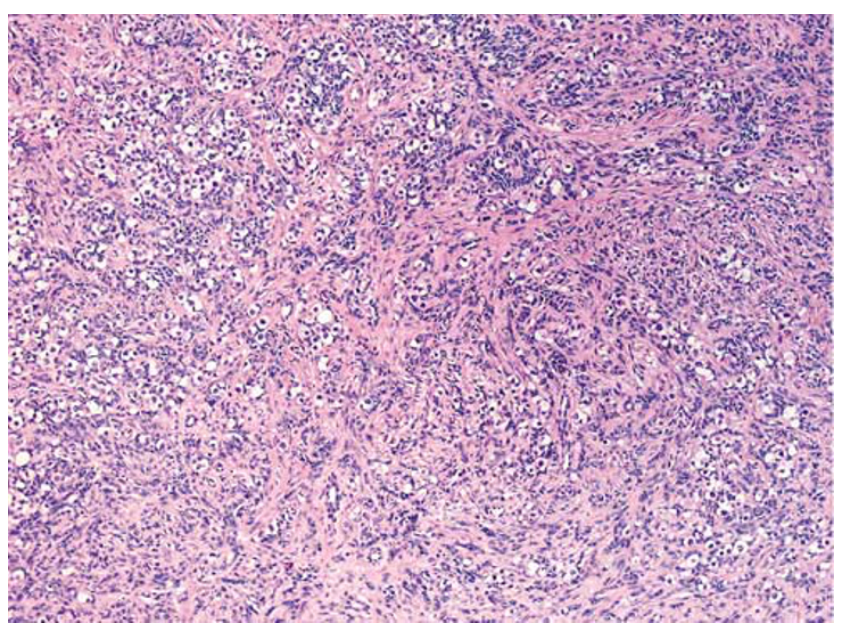

Figure 36 Sex cord-stromal tumor of testis unclassified with entrapped germ cells. This picture may be misconstrued as a mixed germ cell sex cord stromal neoplasm but in the latter, the germ cells are neoplastic whereas here they are entrapped benign cells. 
their resemblance to normal spermatogonia having round nuclei without prominent nucleoli contrasting with the 'squared off' nuclei with prominent nucleoli of neoplastic germ cells as seen in typical seminoma or intratubular germ cell neoplasia unclassified. The usual focal distribution of the germ cells and association with seminiferous tubules containing similar cells also indicated that the germ cells were nonneoplastic. Further support for such a nature may be provided by obtaining a negative reaction with the periodic acid-schiff stain and immunohistochemical markers of neoplastic germ cells such as PLAP. A diploid DNA content has also been found in the germ cells in the cases studied, in contrast to the finding expected in neoplastic germ cells. The admixed germ cells are typically most conspicuous at the periphery of the neoplasm as clusters but may be seen more centrally as scattered cells. This phenomenon may raise the consideration of a mixed germ cell sex-cord stromal tumor, a convincing testicular example of which we have not encountered.

In one unique case a Sertoli cell tumor appeared to collide with a seminoma and incorporated some of its neoplastic germ cells. ${ }^{54}$

The third circumstance in which the rare mixed germ cell sex cord-stromal tumor is mimicked arises when a sex cord-stromal tumor, usually an adult granulosa cell tumor or unclassified sex cordstromal tumor, has lutein-type cells with abundant pale cytoplasm suggesting germ cells. The nuclei of the putative germ cells have smaller nuclei than germ cells, the cytoplasm is lipid-rich and, if necessary, immunohistochemical stains will disclose their nongerm cell nature.

\section{Role of immunohistochemistry in the differential diagnosis of sex cord-stromal tumors placed in context of other diagnostic features}

Once immunohistochemistry became available in diagnostic pathology it was not long until its potential role in the evaluation of sex cord tumors and their mimics was investigated. Given the overlap in patterns of sex cord tumors and diverse other lesions, it seemed logical that it might help in this area and this has been borne out. Despite the aid it may provide in some very specific situations, it must be stressed that a combination of awareness of patient age, clinical features that may be associated with tumors (some expected, some unexpected), stage of the tumor, laterality (unilateral vs bilateral), gross features, knowledge of morphologic variations, thorough sampling, and use of conventional special stains will enable the correct diagnosis to be made in the great majority of cases. Examples of some of these issues and then common helpful immunohistochemical findings will be given. In general, there are more problem areas in ovarian sex cord tumor evaluation.

Space does not allow for consideration of all the nonimmunohistochemical issues but some in each category just listed are noted as examples. Age can be important in the evaluation of sex cord tumors in each gonad, the typical very young age of patients with testicular juvenile granulosa cell tumor and the youth of patients with ovarian retiform SLCTs (vs the usual age of patients with serous tumors) being striking examples. Although androgenic manifestations are typical of ovarian SLCTs, neoplasms that can mimic them, such as Krukenberg tumors, may be virilizing. As sex cord tumors are almost always stage I, higher stage tumors are statistically unlikely to be sex cord tumors. Gonadal sex cord tumors of all types (except the large cell calcifying Sertoli cell tumors of the testis) are almost always unilateral so bilaterality always should make the diagnosis of a sex cord tumor suspect.

The Krukenberg tumor (mimic of SLCT), metastatic melanoma (mimic of granulosa cell tumor in the ovary and granulosa or Sertoli cell tumor in the testis) and metastatic endometrial stromal sarcoma (mimic of either granulosa cell tumor or SLCT of the ovary) are three good examples of the problems metastatic tumors may cause. There are many variations in the morphology of sex cord tumors as considered above and the mere awareness of them is fundamental to making the correct diagnosis, and thorough sampling to uncover diagnostic foci, for example typical granulosa cell tumor in a neoplasm that is predominantly characterized by bizarre nuclei is also crucial. Stains for mucin to highlight the signet-ring cells of a Krukenberg tumor, for fat to show that cytoplasmic clarity is due to lipid in a Sertoli cell tumor, and for reticulum in the differential diagnosis of cellular fibroma from diffuse adult granulosa cell tumor are three of several potential uses of conventional special stains.

The above comments notwithstanding, either as confirmation of the favored diagnosis, or to help resolve a particular diagnostic challenge, focused immunohistochemical evaluation is undoubtedly a source of crucial aid on occasion. One of the early explorations of this area was the study of Aguirre et $a 5^{55}$ that established that epithelial membrane antigen (EMA) positivity was exhibited by sex cord-like formations in endometrioid carcinomas but not by sex cord formations themselves. Relatively soon thereafter inhibin positivity in sex cord cells but not in the cells of surface epithelial tumors (with rare exceptions) added to the aid provided by immunohistochemistry in this area. ${ }^{56-62}$ The next development of note was the recognition by two groups independently ${ }^{18,63}$ that calretinin, previously considered to mark selectively mesothelial cells, also stained sex cord cells and other papers have borne this out. ${ }^{63-65}$ The above combined findings have established the triad of EMA positive, inhibin negative, and calretinin negative as a strong argu- 
ment against a sex cord tumor, the converse results favoring it. As noted earlier, typical granulosa cell tumors may be inhibin negative. The specific differential diagnosis just referred to is rarely, if ever, a problem in testicular pathology, but inhibin staining may help in determining that an unusual testicular neoplasm is in the sex cord family, for instance, in the distinction of an unusual appearing juvenile granulosa cell tumor from yolk sac tumor, although always in conjunction with stains for alpha-fetoprotein. It should be noted, however, that one large study ${ }^{66}$ showed staining of only a minority of Sertoli cell tumors in contrast to all the Leydig cell tumors in that series. Accordingly, a negative inhibin result cannot be used as an argument against the diagnosis of Sertoli cell tumor. Sex cord tumors may also be positive for melan- ${ }^{67}$ and $C D 99^{68}$ but these are of lesser importance in daily practice than those already considered.

One of the first immunostains evaluated in diagnostic pathology, for alphaprotein, is of course helpful in the yolk sac tumor vs nonyolk sac tumor differential but the focality of staining in some typical yolk sac tumors should be emphasized. The well-known markers for malignant melanoma can aid in establishing that diagnosis, rather than, for example, granulosa or Sertoli cell tumor, which we have seen it closely mimic. An issue specific to the ovary is positive staining for thyroglobulin in cases of struma with a small acinar pattern that can strikingly simulate Sertoli cell tumors. The more recently available marker, TTF-1, is also useful in this situation. The overall literature on immunostaining of testicular tumors, from the practical viewpoint, is less extensive than that for the ovary. ${ }^{69}$ One of the best known uses of immunohistochemistry, staining of prostate epithelial cells for PSA or PSAP, may have a role in testicular pathology in confirming, or arguing against if negative, a diagnosis of metastatic prostatic carcinoma which rarely, if acinar differentiation dominates, might suggest a sex cord tumor. The differential diagnosis of seminoma vs Sertoli cell tumor, as mentioned in Dr Ulbright's contribution, can be facilitated by staining for a recently described nuclear transcription factor, Oct 3/4, which is consistently negative in sex cord tumors but positive in seminoma. The combination of inhibin positive and PLAP negative is also helpful in affirming a diagnosis of Sertoli cell tumor with a seminoma-like pattern. A number of other immunohistochemical findings have been investigated in gonadal tumor pathology but this synopsis covers those we have found helpful with any frequency.

\section{References}

1 Meyer R. Pathology of some special ovarian tumors and their relation to sex characteristics. Am J Obstet Gynecol 1931;22:697-713.
2 Teilum G. Special Tumors of Ovary and Testis. Comparative Pathology and Histological Identification, 1st edn. Munksgaard: Copenhagen, 1971.

3 Morris JM, Scully RE. Endocrine Pathology of the Ovary. The C.V. Mosby Co.: St. Louis, 1958.

4 Scully RE, Young RH, Clement PB. Tumors of the Ovary, Maldeveloped Gonads, Fallopian Tube, and Broad Ligament. Atlas of Tumor Pathology, 3rd Series, No. 23. Armed Forces Institute of Pathology: Washington, DC, 1998.

5 Ulbright TM, Amin MB, Young RH. Tumors of the Testis, Adnexa, Spermatic Cord and Scrotum. Atlas of Tumor Pathology, 3rd Series, No. 25. Armed Forces Institute of Pathology: Washington, DC, 1999.

6 Young RH, Koelliker DD, Scully RE. Sertoli cell tumors of the testis, not otherwise specified. A clinicopathologic analysis of 60 cases. Am J Surg Pathol 1998; 22:709-721.

7 Henley JD, Young RH, Ulbright TM. Malignant Sertoli cell tumors of the testis. A study of 13 examples of a neoplasm frequently misinterpreted as seminoma. Am J Surg Pathol 2002;26:541-550.

8 Harms D, Kock LR. Testicular juvenile granulosa cell and Sertoli cell tumours: a clinicopathologic study of 29 cases from the Kiel Paediatric Tumour Registry. Virchow Arch 1997;430:301-309.

9 Jacobsen GK. Malignant Sertoli cell tumor of the testis. J Urol Pathol 1993;1:233-255.

10 Zukerberg LR, Young RH, Scully RE. Sclerosing Sertoli cell tumor of the testis: a report of 10 cases. Am J Surg Pathol 1991;15:829-834.

11 Collins DH, Symington T. Sertoli-cell tumour. Br J Urol 1964;25(Suppl):52-61.

12 Proppe KH, Scully RE. Large-cell calcifying Sertoli cell tumor of the testis. Am J Clin Pathol 1980;74:607-619.

13 Carney JA, Gordon H, Carpenter PC, et al. The complex of myxomas, spotty pigmentation, and endocrine overactivity. Medicine 1985;64:270-283.

14 Kratzer SS, Ulbright TM, Talerman A, et al. Large cell calcifying Sertoli cell tumor of the testis: a study of six malignant and six benign cases and a review of the literature. Am J Surg Pathol 1997;21:1271-1280.

15 Venara M, Rey R, Bergada I, et al. Sertoli cell proliferations of the infantile testis. An intratubular form of Sertoli cell tumor? Am J Surg Pathol 2001;25: 1237-1244.

16 Amin MB, Young RH, Scully RE. Large cell hyalinizing Sertoli cell tumor of the testis: a distinctive estrogenic tumor of boys with Peutz-Jeghers syndrome (PJS): a report of six cases. Mod Pathol 2001;14:100A.

17 Young RH, Scully RE. Ovarian Sertoli cell tumors. A report of 10 cases. Int J Gynecol Pathol 1984;2: 349-363.

18 Oliva E, Alvarez T, Young RH. Sertoli cell tumors of the ovary. A clinicopathologic and immunohistochemical study of 54 cases. Am J Surg Pathol, in press.

19 Young RH, Welch WR, Dickersin GR, et al. Ovarian sex cord tumor with annular tubules. Review of 74 cases including 27 with Peutz-Jeghers syndrome and four with adenoma malignum of the cervix. Cancer 1982;50:1384-1402.

20 Tavassoli FA, Norris HJ. Sertoli tumors of the ovary. A clinico-pathologic study of 28 cases with ultrastructural observations. Cancer 1980;46:2281-2297.

21 Solh HM, Azoury RS, Najjar SS. Peutz-Jeghers syndrome associated with precocious puberty. J Pediatrics 1983;103:593-595. 
22 Ferry JA, Young RH, Engel G, et al. Oxyphilic Sertoli cell tumor of the ovary: a report of three cases, two in patients with the Peutz-Jeghers syndrome. Int J Gynecol Pathol 1994;13:259-266.

23 Young RH, Scully RE. Ovarian Sertoli-Leydig cell tumors with a retiform pattern: a problem in histopathologic diagnosis. A report of 25 cases. Am J Surg Pathol 1983;7:755-771.

24 Young RH, Scully RE. Differential diagnosis of ovarian tumors based primarily on their patterns and cell types. Semin Diagn Pathol 2001;18:181-235.

25 Young RE, Scully RE. Ovarian sex cord-stromal tumors with bizarre nuclei: a clinicopathologic analysis of 17 cases. Int J Gynecol Pathol 1983;1:325-335.

26 Young RH, Dudley AG, Scully RE. Granulosa cell, Sertoli-Leydig cell and unclassified sex cord-stromal tumors associated with pregnancy. A clinicopathological analysis of thirty-six cases. Gynecol Oncol 1984;18:181-205.

27 Young RH, Prat J, Scully RE. Ovarian Sertoli-Leydig cell tumors with heterologous elements (i) Gastrointestinal Epithelium and Carcinoid. A clinicopathologic analysis of thirty-six cases. Cancer 1982;50: 2448-2456.

28 Prat J, Young RH, Scully RE. Ovarian Sertoli-Leydig cell tumors with heterologous elements (ii) Cartilage and Skeletal Muscle. A clinicopathologic analysis of twelve cases. Cancer 1982;50:2465-2475.

29 Roth LM, Slayton RE, Brady LW, et al. Retiform differentiation in ovarian Sertoli-Leydig cell tumors. A clinicopathologic study of six cases from a gynecologic oncology group study. Cancer 1985;55:10931098.

30 Talerman A. Ovarian Sertoli-Leydig cell tumor (androblastoma) with retiform pattern. A clinicopathologic study. Cancer 1987;60:3056-3064.

31 Mooney EE, Nogales FF, Bergeron C, et al. Retiform Sertoli-Leydig cell tumors: clinical, morphological and immunohistochemical findings. Histopathology 2002;41:110-117.

32 Young RH, Perez-Atayde AR, Scully RE. Ovarian Sertoli-Leydig cell tumor with retiform and heterologous elements. Report of a case with hepatocytic differentiation and elevated serum alpha-fetoprotein. Am J Surg Pathol 1984;8:709-718.

33 Gagnon S, Tetu B, Silva EG, et al. Frequency of $\alpha-$ fetoprotein production by Sertoli-Leydig cell tumors of the ovary: an immunohisto-chemical study of eight cases. Mod Pathol 1989;2:63-67.

34 Mooney EE, Nogales FF, Tavassoli FA. Hepatocytic differentiation in retiform Sertoli-Leydig cell tumors: distinguishing a heterologous element from Leydig cells. Hum Pathol 1999;30:611-617.

35 Ahmed E, Young RH, Scully RE. Adult granulosa cell tumor of the ovary with foci of hepatic cell differentiation. A report of four cases and comparison with two cases of granulosa cell tumor with Leydig cells. Am J Surg Pathol 1999;23:1089-1093.

36 Zaloudek C, Norris HJ. Granulosa tumors of the ovary in children. A clinical and pathologic study of 32 cases. Am J Surg Pathol 1982;6:503-512.

37 Young RH, Dickersin GR, Scully RE. Juvenile granulosa cell tumor of the ovary. A clinicopathologic analysis of 125 cases. Am J Surg Pathol 1984;8: 575-596.

38 Biscotti CV, Hart WR. Juvenile granulosa cell tumors of the ovary. Arch Pathol Lab Med 1989;113:40-46.
39 Young RH, Oliva E, Scully RE. Luteinized adult granulosa cell tumors of the ovary: a report of four cases. Int J Gynecol Pathol 1994;13:302-310.

40 Mostofi FK, Theiss EA, Ashley DJB. Tumors of specialized gonadal stroma in human male subjects. Cancer 1959;12:944-957.

41 Jimenez-Quintero LP, Ro JY, Zavala-Pompa A, et al. Granulosa cell tumor of the adult testis: a clinicopathologic study of seven cases and a review of the literature. Hum Pathol 1993;24:1120-1126.

42 Nistal M, Lazaro R, Garcia J, et al. Testicular granulosa cell tumor of the adult type. Arch Pathol Lab Med 1992;116:284-287.

43 Morgan DR, Brame KG. Granulosa cell tumour of the testis displaying immunoreactivity for inhibin. $\mathrm{Br}$ J Urol International 1999;83:731-732.

44 Crump WD. Juvenile granulosa cell (sex cord-stromal) tumor of fetal testis. Urology 1983;129:1057-1058.

45 Lawrence WD, Young RH, Scully RE. Juvenile granulosa cell tumor of the infantile testis. A report of fourteen cases. Am J Surg Pathol 1985;9:87-94.

46 Kaplan GW, Cromie WJ, Kelalis PP, et al. Gonadal stromal tumors: a report of the prepubertal testicular tumor registry. J Urol 1986;136:300-302.

47 Goswitz JJ, Pettinato G, Manivel JC. Testicular sex cord-stromal tumors in children: clinicopathologic study of sixteen children with review of literature. Pediatr Path Lab Med 1996;16:451-470.

48 Perez-Atayde AR, Joste N, Mulhern H. Juvenile granulosa cell tumor of the infantile testis. Evidence of a dual epithelial-smooth muscle differentiation. Am J Surg Pathol 1996;20:72-79.

49 Groisman GM, Dische MR, Fine EM, et al. Juvenile granulosa cell tumor of the testis: a comparative immunohistochemical study with normal infantile gonads. Pediatr Pathol 1993;13:389-400.

50 Young RH, Lawrence WD, Scully RE. Juvenile granulosa cell tumor-another neoplasm associated with abnormal chromosomes and ambiguous genitalia. A report of three cases. Am J Surg Pathol 1985;9: 737-743.

51 Seidman JD. Unclassified gonadal stromal tumors: a clinicopathologic study of 32 cases. Am J Surg Pathol 1996;20:699-706.

52 Talerman A, Hughesdon PE, Anderson MC. Diffuse nonlobular ovarian androblastoma usually associated with feminization. Int J Gynecol Pathol 1982;1: 155-171.

53 Kay R. Prepubertal testicular tumor registry. J Urol 1993;150:671-674

54 Ulbright TM, Srigley JR, Reuter VE, et al. Sex cordstromal tumor of the testis with entrapped germ cells. A lesion mimicking unclassified mixed germ cell sex cord-stromal tumors. Am J Surg Pathol 2000;24: 535-542.

55 Aguirre P, Thor AD, Scully RE. Ovarian endometrioid carcinomas resembling sex cord-stromal tumors: an immunohistochemical study. Int J Gynecol Pathol 1989;8:364-373.

56 Guerrieri C, Frånlund B, Malmström H, et al. Ovarian endometrioid carcinomas simulating sex cord-stromal tumors: a study using inhibin and cytokeratin 7 . Int J Gynecol Pathol 1998;17:266-271.

57 Riopel MA, Perlman EJ, Seidman JD, et al. Inhibin and epithelial membrane antigen immunohistochemistry assist in the diagnosis of sex cord-stromal tumors and provide clues to the histogenesis of hypercalcemic 
small cell carcinomas. Int J Gynecol Pathol 1998; 17:46-53.

58 Rishi M, Howard LN, Bratthauer GL, et al. Use of monoclonal antibodies against human inhibin as a marker for sex cord-stromal tumors of the ovary. Am J Surg Pathol 1997;21:583-589.

59 McCluggage WG, Maxwell P, Sloan JM. Immunohistochemical staining of ovarian granulosa cell tumors with monoclonal antibodies against inhibin. Hum Pathol 1997;28:1034-1038.

60 Stewart CJR, Jeffers MD, Kennedy A. Diagnostic value of inhibin immunoreactivity in ovarian gonadal stromal tumours and their histological mimics. Histopathology 1997;31:67-74.

61 Zheng W, Sung CJ, Hanna I, et al. and $\beta$ subunits of inhibin/activin as sex cord-stromal differentiation markers. Int J Gynecol Pathol 1997;16:263-271.

62 Kommoss F, Oliva E, Bhan AK, et al. Inhibin expression in ovarian tumors and tumor-like lesions: an immunohistochemical study. Mod Pathol 1998;11: 656-664.

63 McCluggage WG, Maxwell P. Immunohistochemical staining for calretinin is useful in the diagnosis of ovarian sex cord-stromal tumors. Histopathology 2001;38:403-408.

64 Movahedi-Lankarani S, Kurman RJ. Calretinin, a more sensitive but less specific marker than $\alpha$-inhibin for ovarian sex cord-stromal neoplasms. Am J Surg Pathol 2002;26:1477-1483.

65 Cao QJ, Jones JG, Li M. Expression of calretinin in human ovary, testis, and ovarian sex cord-stromal tumors. Int J Gynecol Pathol 2001;20:346-352.

66 Kommoss F, Oliva E, Bittinger F, et al. Inhibin- $\alpha$, CD99, HEA125, PLAP, and Chromogranin immunoreactivity in testicular neoplasms and the androgen insensitivity syndrome. Hum Pathol 2000;31:1055-1061.

67 Stewart CJR, Nandini CL, Richmond JA. Value of A103 (melan-A) immunostaining in the differential diagnosis of ovarian sex cord-stromal tumours. J Clin Pathol 2000;53:206-211.

68 Loo KT, Leung AKF, Chan JKC. Immunohistochemical staining of ovarian granulosa cell tumors with MIC 2 antibody. Histopathology 1995;27:388-390.

69 Iczkowski KA, Bostwick DG, Roche PC, et al. Inhibin A is a sensitive and specific marker for testicular sex cord-stromal tumors. Mod Pathol 1998;11:774-779. 